\title{
Indian Household Balance Sheet: Accounting issues and wealth estimation
}

May 2020

\author{
Akash Malhotra \\ CPL Fellow (2017 - 2018)
}

Citizens for Public Leadership (CPL) is an independent and nonpartisan movement focused on advocating for progressive public policy in India. CPL is an apolitical non-profit with the sole objective of strengthening the capacity of our youth to take up leadership challenges in the public sphere.

Disclaimer: This paper should not be reported as representing the views of the Citizens for Public Leadership (CPL). The views expressed are those of the author(s) and do not necessarily reflect those of the CPL. 


\title{
Indian Household Balance Sheet: Accounting issues and wealth estimation
}

\author{
Akash Malhotra ${ }^{a}$,\# \\ ${ }^{a}$ Centre for Economic Studies and Planning, Jawaharlal Nehru University, New Delhi, India
}

Version 1: Mar 2019

Version 2: May 2020

\section{Abstract}

This paper presents a novel estimate of Indian household balance sheet (HBS) starting from 1970-71 to 2017-18 and studies the evolution of Indian household finance in an international context. Comparative analysis suggests that the Global Wealth Databook, the annual publication of Credit Suisse Research Institute, has been significantly underestimating both the stock of financial assets and liabilities; whereas, Reserve Bank of India, in its recent publication, is marginally overestimating the stock of financial assets and institutional liabilities. An analysis of the Net financial position of the Indian household sector reveals that India is presently facing a Five Balance Sheet challenge-critical HBS leverage ratios have continued to climb up even during the global economic recovery period post-2010. The author recommends close monitoring and higher frequency publication of HBS.

JEL classification: D14, E01, E21, G51, O57

Keywords:

Household Balance Sheet, Wealth accumulation, Household debt, Financial sectoral accounts, India.

\footnotetext{
\# Corresponding author at: Centre for Economic Studies and Planning, Jawaharlal Nehru University, New Delhi, 110067, India.

E-mail addresses: akash_malhotra@iitb.ac.in (A. Malhotra)
} 


\section{Introduction}

Sectoral balance sheets offer a key stock perspective and shed light on the structure of sectoral finance, wealth accumulation and the associated default risks, along with other statistical and macroeconomic issues. The national accounts are supposed to have balance sheets for each sector. Unfortunately, at the time of writing, India does not have an official balance sheet for the household sector. In most high-income countries Household Balance Sheets are available quarterly, or at least annually (e.g., OECD publishes this data for its member countries in "Households' financial assets and liabilities"). There is certainly a very high user demand for such data (Shorrocks et al., 2019). Recently, an increasing number of economies have begun completing their national accounts by publishing sectoral balance sheets, at least for financial assets and liabilities (Shorrocks et al., 2019). Alternative estimates of the HBS for China have been released, viz. Li (2018) and Piketty et al. (2019). India has endorsed the second phase of the G20 Data Gaps Initiative (DGI-2) and accordingly, NSC (2018) made recommendations related to timeliness and higher periodicity of financial accounts release, statelevel coverage and inclusion of new aspects such as flows versus stocks in the sectoral accounts, among other methodological improvements. This paper is an attempt in the same direction - here, I compile a balance sheet for the Indian household sector which presents the evolution of outstanding stock of household wealth and debt.

Compared with debates on income growth, household wealth accumulation in India has received less consideration from academics as well as policymakers. This is partly because, in policy circles and academic debates alike, income-particularly the GDP figures-commands more attention than wealth. But it is also because of the dearth of appropriate data on household wealth or debt in the country. Even though India has a long history of collecting data on household debt through its decennial wealth surveys, indebtedness in the household sector continues to be underestimated, or 
at least to be perceived as less of a problem. Presently, the decennial All India Debt and Investment Survey (AIDIS) serves as the lone source of primary data for household wealth in India. Based on the AIDIS data, the Credit Suisse Research Institute has been publishing yearly Global Wealth Databook (GWD) since 2010, which contains estimates for the stock of household wealth and debt starting from the year 2000 for a large number of countries, including India. The estimates of HBS provided in GWD are widely-used in policy and journalistic circles. But as I illustrate in this paper, the GWD has been misjudging the financial position of Indian households. For the first time ${ }^{1}$, a preliminary estimate of the household balance sheet has been released by the Reserve Bank of India along with RBI (2019) for the period FY12 - FY18, but as I show in this paper, the HBS presented in RBI (2019) is plagued with accounting errors and as a consequence, overestimates the stock of household financial assets and liabilities alike.

Preparing balance sheets for any sector requires the availability of data on its stocks of assets and liabilities. Such data is not available in the Indian National Accounts Statistics (NAS) simply because the data collection efforts of the Indian Ministry of Statistics and Programme Implementation (MoSPI) focus on data needed to compile the current accounts, rather than on data relevant to accumulation accounts. The approach we use here, to derive the HBS, is a perpetual inventory approach that relies on accumulating Flow-of-Funds (FoF) while making appropriate technical adjustments and assumptions regarding the initial value of stock. The FoF data are available at least back to 1970-71. The availability of FoF data is going to form the crux of the methodology employed for the compilation of HBS here. All things considered, this paper attempts to create a paradigm for future studies aimed at improving the reliability of the Indian HBS data and estimation methods. The

\footnotetext{
${ }^{1}$ Prior to RBI (2019), a partial balance sheet of household sector was released with RBI (2018) which reported data on outstanding positions for a select few financial instruments but did not report stock of gross financial assets and liabilities or net financial position of household sector.
} 
rest of the paper is organized as follows: Section 2 describes the data sources and major accounting issues related to household balance sheet compilation for India. Section 3 highlights the deficiencies in the extant HBS estimates and analyses the evolution of the net financial position of Indian household sector over time and the composition of household wealth and debt, as per the HBS computed in this paper. Section 4 compares the structure of Indian household finance with that found in the other regions and economies of the world and diagnoses the risks arising from increasing household indebtedness. Section 5 presents some concluding reflections and suggestions pertinent to future avenues of research.

\section{Data and Methodology: Major accounting issues}

According to Indian system of National Accounts (CSO, 2012), "household" sector in India comprises of individuals, unincorporated establishments (like sole proprietorships and partnerships), non-profit institutions serving households (like educational institutions, charitable trusts, NGOs, political parties, etc.) and all non-government non-corporate enterprises (like farm and non-farm businesses). Thus, in addition to individuals, the household sector also includes all enterprises/economic units that are not covered in the other three domestic sectors ${ }^{2}$ of the economy. Technically, this interpretation is slightly different from the definition of "households" as proposed by the UN System of National Accounts (SNA, 2008) which includes only individuals and group of persons sharing the same living accommodation or pooling some or all of their income and wealth, wherein each member of the household have some claim upon the collective resources of the household, and thereby excludes non-profit institutions. In this article, we will continue to follow the CSO (2012) definition of

\footnotetext{
2 The Indian FoF categorize the economy into four domestic sectors: financial corporations, non-financial corporations, general government, household; and one external sector: rest of the world (RBI, 2015).
} 
"household", unless stated otherwise ${ }^{3}$. In NAS, the gross financial savings made by the household sector is estimated by net changes in the financial position of households for a list of financial assets: currency, deposits, trade debt, shares and debentures, claims on government, insurance funds, and provident \& pension funds. The annual flows for liabilities are also reported instrument-wise: bank advances, loans and advances by cooperative banks \& societies, loans by financial corporations $\&$ non-banking companies, loans and advances from government, and loans from insurance companies. Since the household sector is an unorganized sector and direct estimates of its balance sheets are not available, the financial flows for various instruments are either estimated through -(i) residual approach, i.e., after duly accounting for such instruments held by public and private corporate sectors, or (ii) through firm information collected from the accounts of counterpart institutions transacting with the households, or (iii) through existing information on sectoral distributions (direct or survey). The only two instruments for which the flow data is directly available are Pension funds and Life Insurance funds:

$$
\begin{gathered}
\Delta(P . F . \& \text { Pension Fund })=\text { Contribution }+ \text { Interest }- \text { Withdrawls } \\
\Delta(\text { Life Insurance Funds })=\text { Income }- \text { Expenditure }
\end{gathered}
$$

Unless stated otherwise, the data on various balance sheet items presented in this paper has been sourced from NAS Statement 5.3: Changes in "Financial assets and liabilities of the household sector". Presently, there is an internal arrangement to supply input data for the preparation of Statement 5.3 from RBI to the Central Statistics Office (CSO). For a detailed exposition of the methodology employed by RBI in compilation of Flow-of-Funds Accounts, the reader may refer to RBI (2015). As per the extant practice, the changes in financial assets and liabilities of the household sector are estimated in the

\footnotetext{
${ }^{3}$ The size of household sector produced from CSO (2012) definition is likely to be larger than that from SNA (2008) definition.
} 
form of financial flows based on counterparty sector data, i.e., from central bank, commercial banks, NBFCs, insurance companies, housing finance companies, mutual funds, general government sector and non-financial corporates, etc. It may be noted that counterparties do not always provide assets and liabilities specific to the household sector to the RBI and in such cases, flows are estimated using multiple rates and ratios based on various sectoral reports. At times, it also involves the logical judgement of the RBI staff. In a personal correspondence with the Reserve Bank of India (dated July 26, 2018) under Right to Information Act, 2005, the author was let known that the stock data are neither published nor preserved by RBI exactly for the above reasons.

However, in my opinion, the above-mentioned circumstances do not pose any serious limitation in reconstructing time-series of stock data by accumulating the flow data over time as the FoF account for the household sector, or for that matter the entire FoF matrix, does incorporate transactions, revaluations and other changes in the volume of assets (OCVA). However, this disaggregation was not compiled separately by RBI until recently ${ }^{4}$. Essentially, the Flow-of-Funds (FoF) accounts, as available in NAS, represent annual changes in stock-period to period changes in the outstanding amounts of financial assets and liabilities. This allows us to use perpetual inventory approach to derive HBS from the household FoF data. The approach relies on accumulating flows over time while making appropriate technical adjustments and assumptions regarding the initial value of stock.

\footnotetext{
${ }^{4}$ Recently with the release of balance sheet data (FY12-FY18) for institutional sectors, RBI (2019) attempted the bifurcation of financial flows into transactions and valuation changes for mutual funds, insurance, pension and provident funds, households and the central bank.
} 


\section{Table 1}

India's Household Balance Sheets, 2003-04 to 2017-18

(all figures are in billion rupees, current prices)

\begin{tabular}{|c|c|c|c|c|c|c|c|c|c|c|c|c|c|c|c|}
\hline Item/Year & 2003-04 & 2004-05 & 2005-06 & $2006-07$ & 2007-08 & 2008-09 & 2009-10 & 2010-11 & 2011-12 & 2012-13 & 2013-14 & 2014-15 & 2015-16 & 2016-17 & $2017-18$ \\
\hline 1. Financial Assets & 29255 & 33727 & 39569 & 47216 & 54940 & 62208 & 72106 & 82905 & 92232 & 102873 & 114780 & 127353 & 142315 & 156699 & 175395 \\
\hline 1.1. Currency & 2905 & 3274 & 3796 & 4468 & 5281 & 6202 & 7172 & 8543 & 9606 & 10721 & 11716 & 13049 & 15055 & 11890 & 16598 \\
\hline 1.2. Deposits & 12094 & 13844 & 16504 & 20908 & 24949 & 29359 & 33508 & 39110 & 44515 & 50577 & 57247 & 63370 & 69815 & 79495 & 84848 \\
\hline 1.2.1. Bank Deposits & 11006 & 12757 & 15414 & 19707 & 23597 & 27775 & 31756 & 37239 & 42499 & 48250 & 54643 & 60436 & 66659 & 76045 & 81147 \\
\hline 1.2.2. Non-banking Deposits & 1207 & 1207 & 1213 & 1258 & 1271 & 1419 & 1604 & 1655 & 1755 & 2034 & 2262 & 2552 & 2732 & 2983 & 3192 \\
\hline 1.2.3. Trade Debt (owned) ${ }^{\Delta}$ & -119 & -120 & -122 & -57 & 81 & 166 & 148 & 216 & 261 & 293 & 341 & 383 & 424 & 467 & 509 \\
\hline 1.3. Shares \& Debentures & 1633 & 1683 & 2017 & 2522 & 3262 & 3211 & 3660 & 3677 & 3842 & 4012 & 4202 & 4405 & 4689 & 5132 & 5762 \\
\hline 1.4. Claims on government & 4054 & 5119 & 5990 & 6182 & 5899 & 5623 & 6058 & 6354 & 6135 & 6064 & 6294 & 6304 & 6983 & 7614 & 8436 \\
\hline 1.5. Insurance funds & 3464 & 4144 & 4979 & 6128 & 7826 & 9355 & 11953 & 14054 & 16011 & 17810 & 19855 & 22848 & 25490 & 29033 & 32537 \\
\hline 1.6. Provident and pension funds & 5105 & 5663 & 6283 & 7008 & 7723 & 8457 & 9756 & 11167 & 12124 & 13689 & 15467 & 17376 & 20283 & 23535 & 27214 \\
\hline 2. Institutional Financial Liabilities & 4908 & 6108 & 7946 & 10772 & 12654 & 14290 & 16324 & 19104 & 22005 & 25309 & 28896 & 32664 & 36518 & 41205 & 48610 \\
\hline 2.1. Bank advances & 4087 & 5207 & 6962 & 9699 & 11494 & 13041 & 14986 & 17676 & 20401 & 23488 & 26512 & 29336 & 32030 & 35490 & 40429 \\
\hline 2.2. Advances from government & 122 & 117 & 112 & 106 & 103 & 101 & 100 & 99 & 102 & 104 & 110 & 112 & 116 & 116 & 124 \\
\hline $\begin{array}{r}\text { 2.3. Advances from other financial } \\
\text { institutions }\end{array}$ & 640 & 723 & 807 & 900 & 987 & 1075 & 1164 & 1252 & 1425 & 1640 & 2197 & 3139 & 4295 & 5522 & 7980 \\
\hline $\begin{array}{r}\text { 2.4. Advances from co-operative non- } \\
\text { credit societies }\end{array}$ & 59 & 62 & 65 & 67 & 69 & 72 & 74 & 77 & 77 & 77 & 77 & 77 & 77 & 77 & 77 \\
\hline 3. Non-institutional Liabilities & 2618 & 3144 & 3940 & 5138 & 5798 & 6278 & 6865 & 7675 & 8426 & 9692 & 11065 & 12508 & 13984 & 15778 & 18614 \\
\hline $\begin{array}{r}\text { 4.a. Net Institutional Financial } \\
\text { Wealth (1-2) }\end{array}$ & 24348 & 27619 & 31623 & 36444 & 42286 & 47919 & 55782 & 63801 & 70227 & 77563 & 85884 & 94689 & 105797 & 115494 & 126784 \\
\hline $\begin{array}{l}\text { 4.b. Net Institutional Financial Wealth } \\
\text { (Moore's estimate in 1951) }\end{array}$ & 24448 & 27719 & 31723 & 36544 & 42386 & 48019 & 55882 & 63901 & 70327 & 77664 & 85984 & 94789 & 105897 & 115594 & 126884 \\
\hline 5. Net Total Financial Wealth $(4 . b-3)$ & 21830 & 24575 & 27784 & 31406 & 36588 & 41740 & 49017 & 56226 & 61901 & 67972 & 74919 & 82281 & 91913 & 99816 & 108270 \\
\hline
\end{tabular}

Source: Author calculations

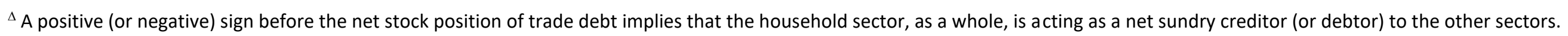




\subsection{Initial Value Assumption: Robustness checks}

The FoF data for Net Institutional Financial Savings (= Gross Financial Saving - Changes in Institutional Financial Liabilities) is available starting from 1950-51. However, constrained by the availability of segregated FoF data for most of the individual financial items (except for Currency, Provident \& Pension Funds, and Shares \& Debentures), we begin cumulating FoF flows starting from 1970-71. The computed household balance sheet has been made available in the Data and Statistical Appendix and an excerpt from the same is presented in Table 1 . The initial stock value for all financial items is assumed to be zero on $31^{\text {st }}$ March 1970 . Now using the FY 1969-70 stock data as a benchmark position, the subsequent stock data are constructed by incrementing the flow data collected from the net changes reported in FoF data for each item. Fortunately, there exists FoF data for Net Institutional Financial Savings, Currency, and Provident \& Pension funds starting from 1950-51 in older CSO records and estimates of stock data on $31^{\text {st }}$ March 1951 for these items in Moore (2007). This allows us to test the validity of our zero initial value assumption and compute the magnitude of deviations caused, if any. Using Moore's estimate for stock of Institutional Financial Wealth on $31^{\text {st }}$ March 1951 and FoF data for Net Institutional Financial savings from 1950-51 to 2017-18, we are able to compile an alternate time series for the stock of Financial Wealth (net of institutional liabilities) held by Indian households, referred to as "Net Institutional Financial Wealth (Moore's estimate in 1951)" in Table 1 (4.a). As apparent from Table 1, the two series (4.a and 4.b) converge and the stock of net institutional financial wealth as estimated by the two series differ only by $0.08 \%$ in $2017-18$. This indicates that our assumption of ascribing zero value to the stock of institutional financial wealth on $31^{\text {st }}$ March 1970 does not cause significant deviations in the recent past as corroborated by Fig. 1 , which shows that deviations become less than 3\% after 1990-91 and further falls below $1 \%$ after 1996-97. Therefore, for the rest of the paper our period of analysis will be from 1990-91, at the 
earliest $^{5}$, for all HBS items with constraints on FoF time series data availability, i.e., items for which FoF data is not available before 1970-71 in NAS. useful

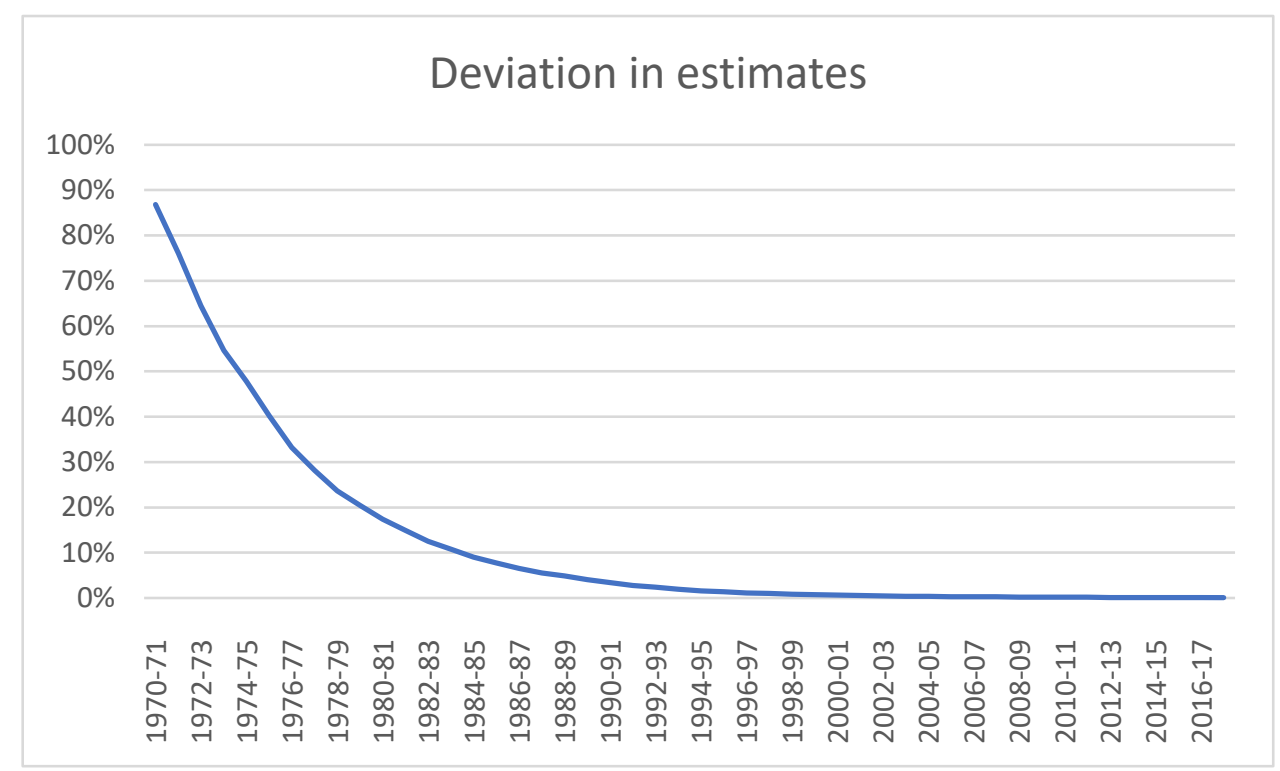

Figure 1. Deviation in Net Institutional Financial wealth as estimated by the two series

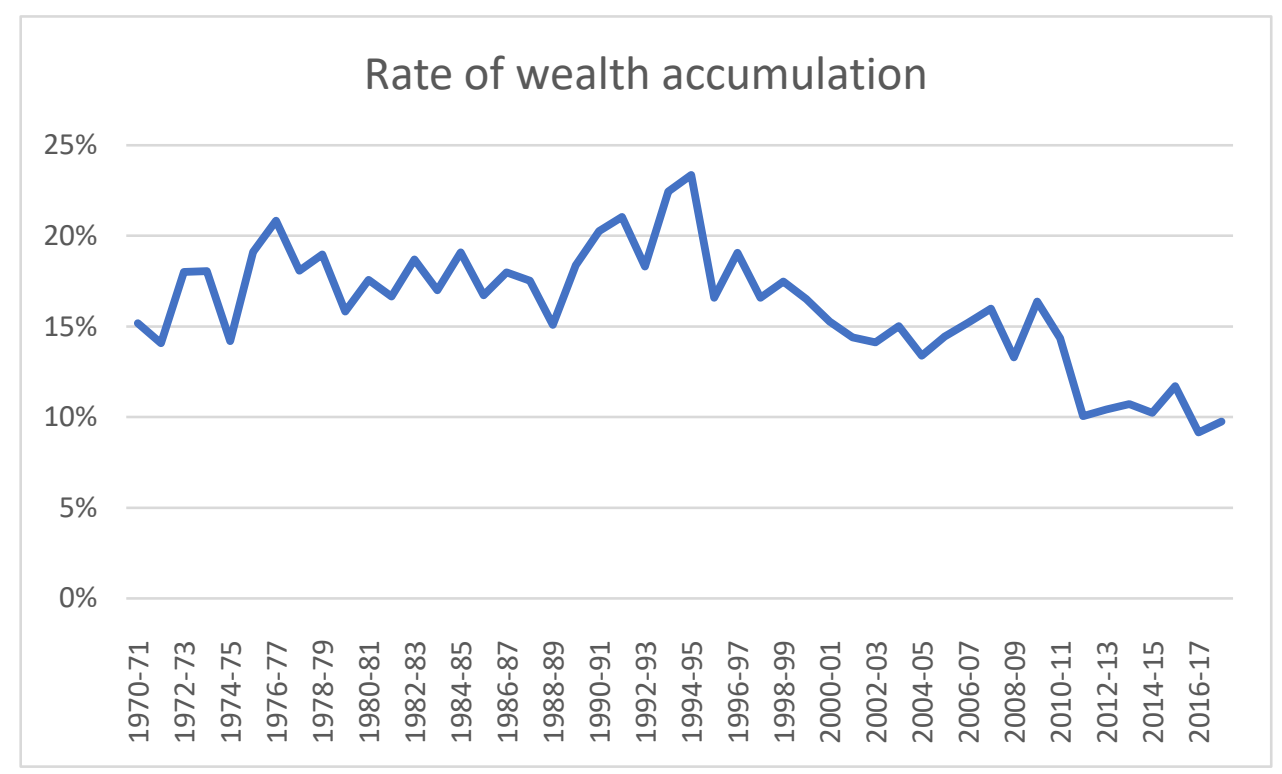

Figure 2. Rate of accumulation of Net Institutional Financial wealth (Moore's estimate in 1951)

An apparent reason for the validity of our assumption is the consistently high rate of financial wealth (net of institutional liabilities) accumulation by Indian households which has remained above or close

\footnotetext{
${ }^{5}$ Determining whether an error lies within a tolerable margin is, ultimately, a subjective exercise. Therefore, I leave the choice of earliest year (starting from which the compiled HBS could be considered reliable) to the judgement of future users of this data. Accordingly, deviations reported in Fig. 1 and 3 shall come in handy while making such judgement calls.
} 
to $10 \%$ (in nominal terms) since $1970-71$ as illustrated in Fig. 2. A consistently high accumulation rate implies that the absolute value of net institutional financial saving in 2017-18 (₹11,290 bn) will dwarf the net institutional financial savings made by Indian households prior to 1970-71 (less than ₹15 bn annually), thereby trivializing the contribution of savings made way back. Notice that the rate of financial wealth accumulation has dipped significantly post 2008 financial crisis from $15 \%$ levels to $10 \%$ levels and has since remained there.

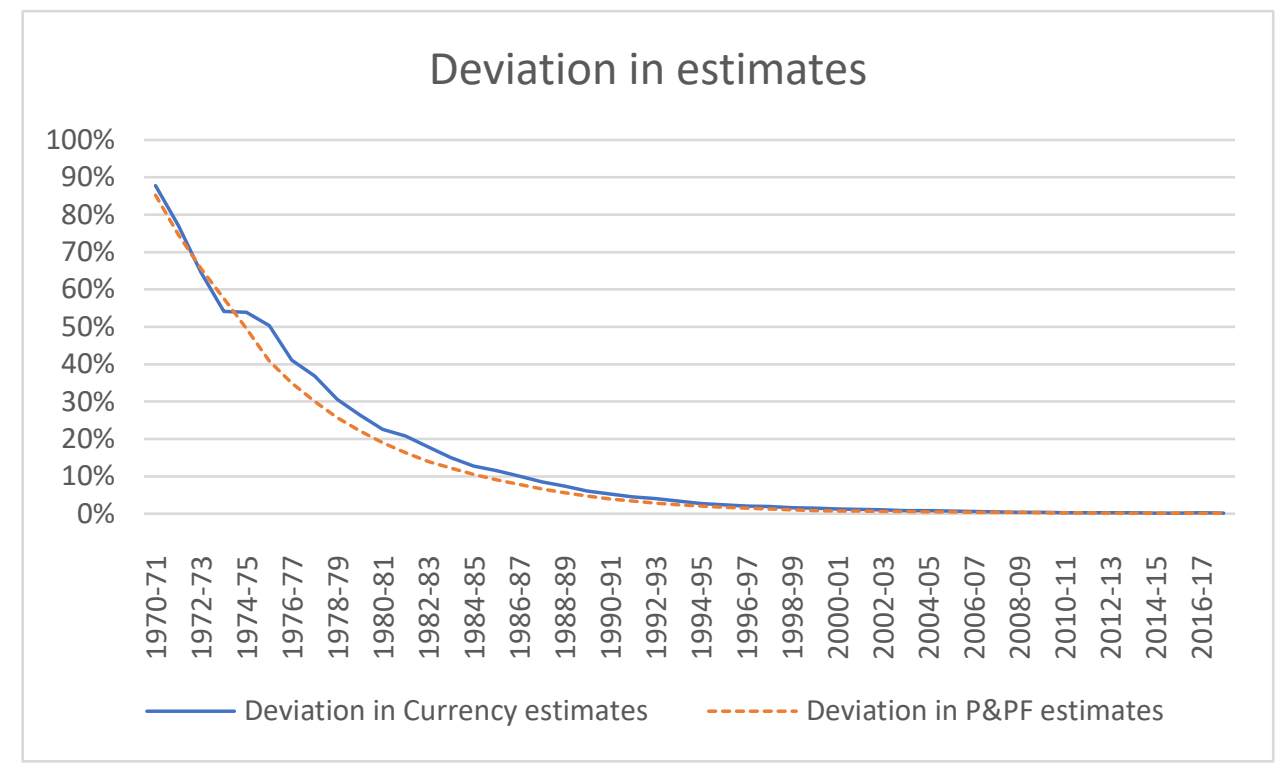

Figure 3. Deviation in Currency and P\&PF as estimated by the two series

The same pattern of convergence is observed for individual items in the household balance sheet: Currency, and Provident \& Pension funds (P\&PF); for both these items, the two estimates have come pretty close in the recent years. The deviations for both Currency and P\&PF have become less than 5\% after 1990-91 (see Fig. 3). In the year 2017-18, the deviation in the two stock estimates for Currency was $0.15 \%$ and for Provident \& pension funds, it was $0.10 \%$. The convergence observed in these series further supports our assumption of ascribing zero value (on 31st March 1970) to the stock of those financial assets/liabilities for which flow data is not available prior to $1970-71$. 


\subsection{Estimating non-institutional credit}

In this article, we do not attempt to estimate the non-financial component of HBS, mainly due to the paucity of reliable flow/stock data for physical assets ${ }^{6}$, viz. land holdings, dwellings, precious metals, automobiles and other consumer durables. We do, however, estimate stock of outstanding cash loans borrowed by households from non-institutional credit agencies such as moneylenders, landlords, traders, input suppliers and so on. The FoF data made available in NAS do not include credit from non-institutional sources and the estimate of stock of debt obtained from FoF data represents only debt raised from institutional agencies. To produce a reasonable estimate of stock of noninstitutional debt, we compute the ratio of non-institutional to institutional household debt at the all-India level from various rounds ${ }^{7}$ of AIDIS and apply these ratios on the stock of institutional debt estimated from RBI's FoF data. The under-reporting of household debt in India's wealth survey is widely recognized in the literature (Shorrocks et al., 2019) and discussed in Section 3.2 in detail. However, it is likely that the survey participants would under-report institutional and noninstitutional debt by roughly the same factor as there is no apparent reason for significant inequality in the magnitude of under-reporting amongst the two types of debt. The ratios for years between various rounds of AIDIS surveys-1981 to 1991, 1991 to 2002 and from 2002 to 2012-are estimated from three separate linear interpolations and the ratio for years post-2012 is ascribed the same value as that in 2012 (see Fig. 4). This imputation is admittedly crude but better than simply disregarding the entire non-institutional debt owed by households. The net total financial wealth, as reported in

\footnotetext{
${ }^{6}$ Note that survey estimates for 'household' holdings in these non-financial assets are available in various rounds of NSSO surveys and All India Debt and Investment Survey (AIDIS) which are conducted from time to time.

${ }^{7}$ We use data from the last four rounds of AIDIS, viz., 1981, 1991, 2002 and 2012. The AIDIS data represents the value of stock on $30^{\text {th }}$ June of the corresponding year. We ascribe the computed ratios for a particular round of AIDIS to $31^{\text {st }}$ March of the corresponding year; for example, the ratio computed from 1991 AIDIS is ascribed to stock at the end of FY91.
} 
Table $1(5)$, is computed by subtracting the outstanding institutional and non-institutional household debt from the stock of financial assets.

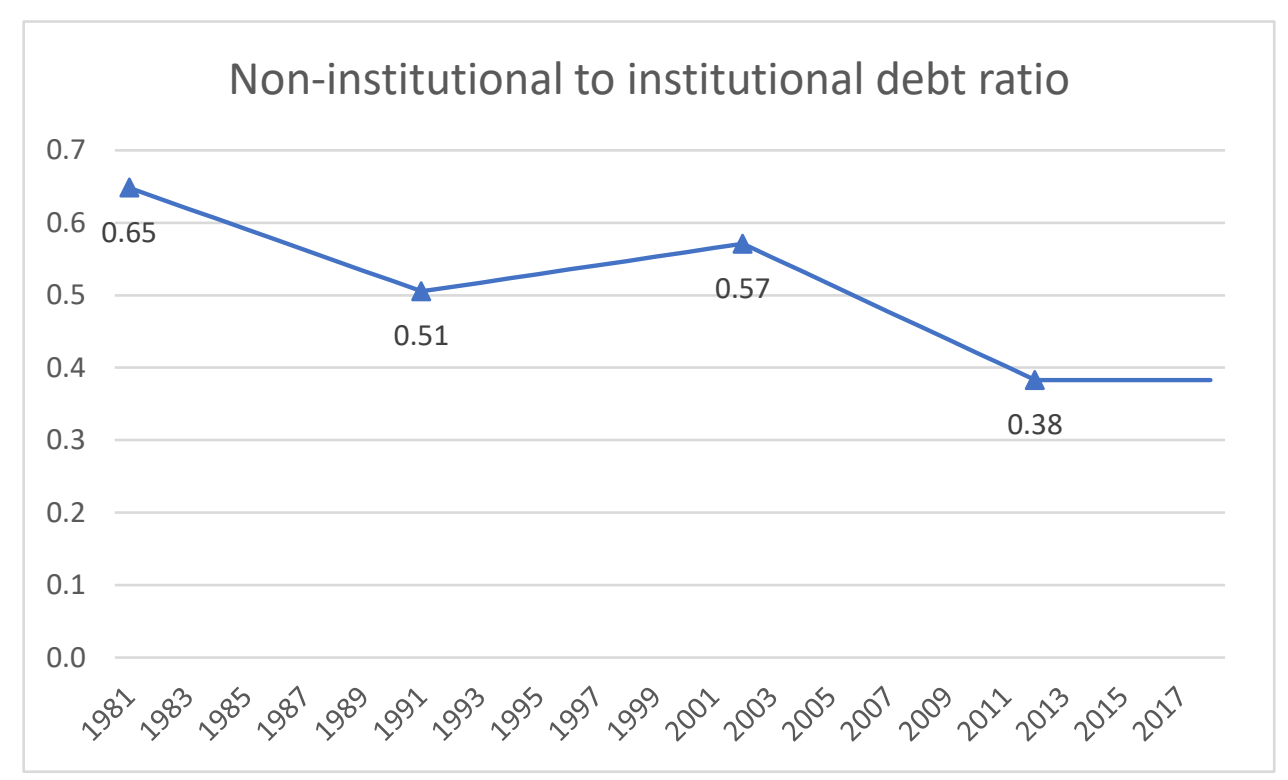

Figure 4. Ratio of non-institutional to institutional household debt (Source: Last four rounds of AIDIS)

\section{Indian Households' Net Financial Position: Wealth and}

\section{composition Analysis}

The Financial Position (net of total liabilities) of the Indian Household sector in 2017-18 was ₹108 trillion. The net total financial wealth per capita, in 2017-18 prices and as adjusted by GDP deflator, has grown significantly from ₹16,720 in 1990-91 to ₹82,272 in 2017-18 (see Fig. 5). In the last three decades, the per capita Financial Wealth (net of total liabilities) has grown on average by $6.2 \%$ annually in real terms. This accumulation has been supported partly by an average $4.1 \%$ annual growth in per capita real Household Disposable Income (see Fig. 5). After adjusting for changes in price levels, the stock of financial assets owned by Indian households has risen from ₹21 trillion in 1990-91 to ₹175 trillion in 2017-18, whereas the outstanding stock of household debt has increased from ₹8 trillion to ₹67 trillion in the same period (see Fig. 6). 


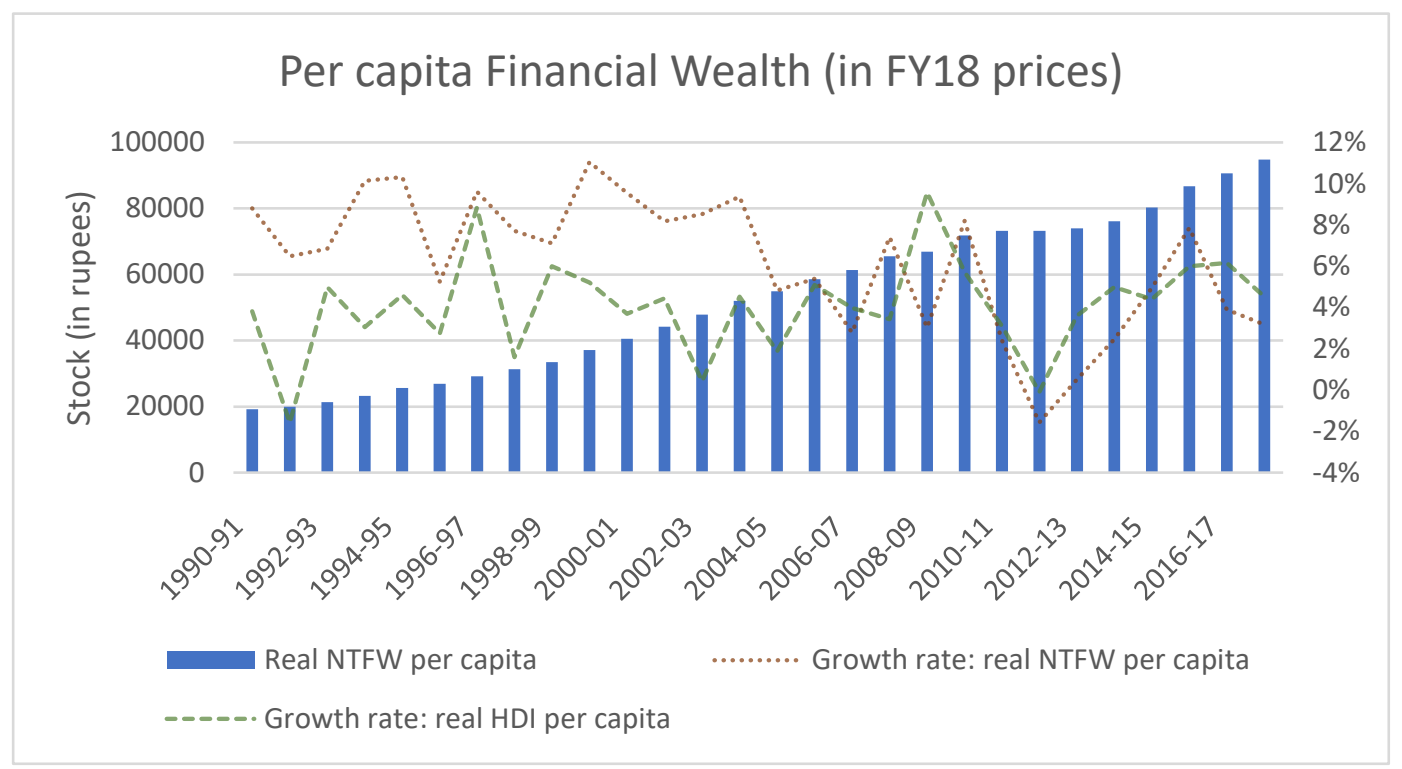

Figure 5. Evolution of per capita Net Total Financial Wealth (NTFW) and Household Disposable Income (HDI)

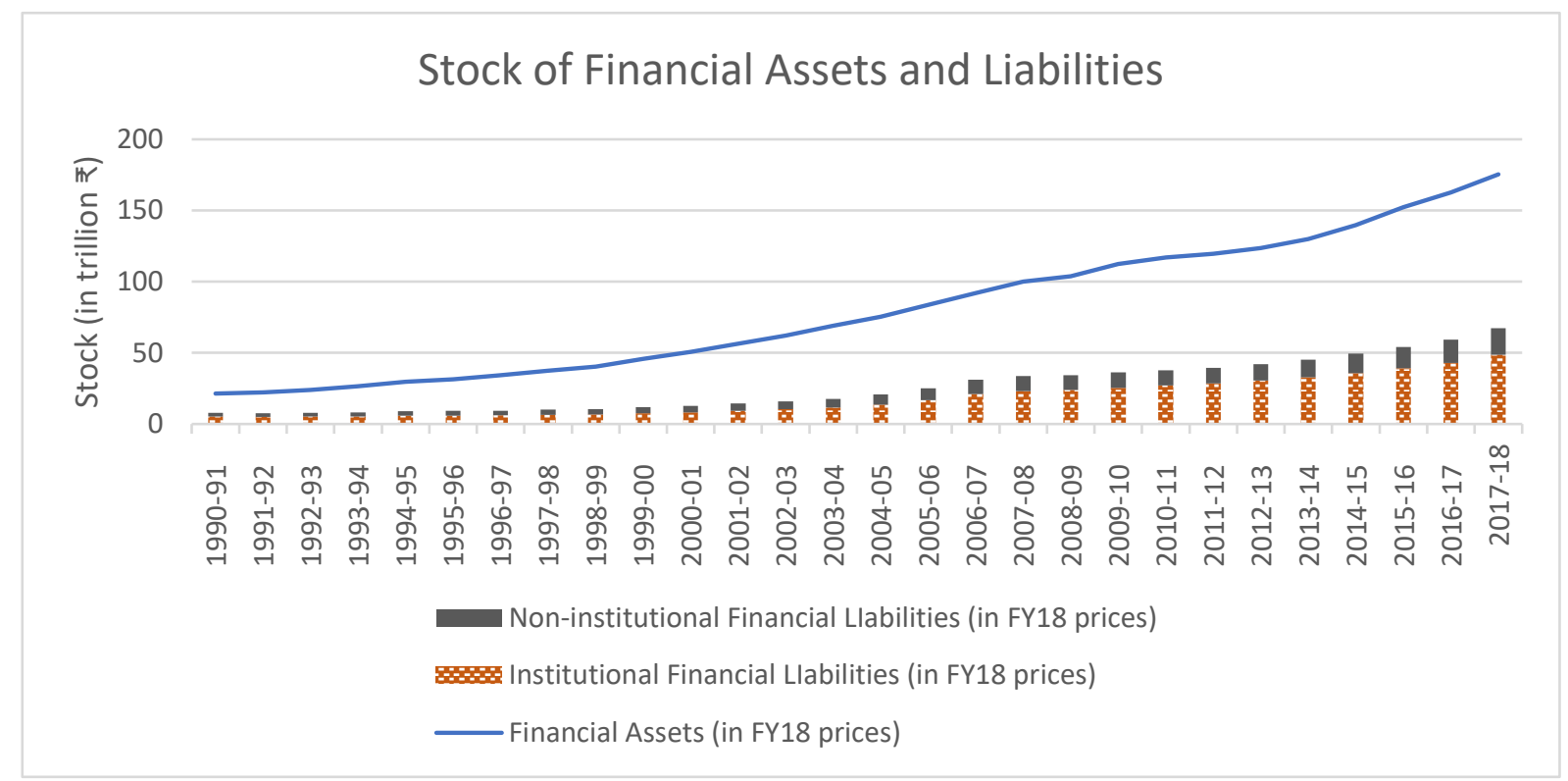

Figure 6. Stock of Financial Assets and Liabilities (in FY18 prices)

The pattern of ownership of financial assets has varied widely owing to a few asset classes as depicted in Fig. 7. The combined share of Currency and Deposits, the most preferred financial instruments, has remained more or less constant (55\% on an average) over time. The share of Life Insurance funds ${ }^{8}$ has increased consistently from $8.1 \%$ in $1990-91$ to $18.6 \%$ in $2017-18$, whereas the share of Provident

\footnotetext{
8 'Life Insurance funds' includes Central or State Governments employees' insurance funds and postal insurance funds. The asset position is estimated from actuarial reserves and other technical reserves for entitlements relating to individual life insurance policies (RBI, 2018).
} 
\& Pension funds ${ }^{9}$ in the total stock of financial assets owned by the household sector has declined gradually from $18.1 \%$ in $1990-91$ to $15.5 \%$ in $2017-18$. The asset class of Shares \& Debentures ${ }^{10}$ offers a surprising observation-its bit in the total household holdings of financial assets was increasing in the early 1990s (from $7.3 \%$ in $1990-91$ to $10.9 \%$ in $1995-96$ ), but then kept on declining and has been in the range of $3 \%-4 \%$ in the last five years. This observation is contrary to the everyday reporting by financial press and also to the claim made by RBI $(2019$, p. 51) that Currency and Deposits combined are losing their share in Indian households' portfolio to equities and debt securities over time. Interestingly, the share lost by the asset class 'Shares and Debentures' between FY96 - FY18 is commensurate with the share gained by Life Insurance funds over the same period. This is not a dramatic shift as the reserves of life insurance funds comprise equities, bonds and other financial instruments that are in effect being held on behalf of the household sector.

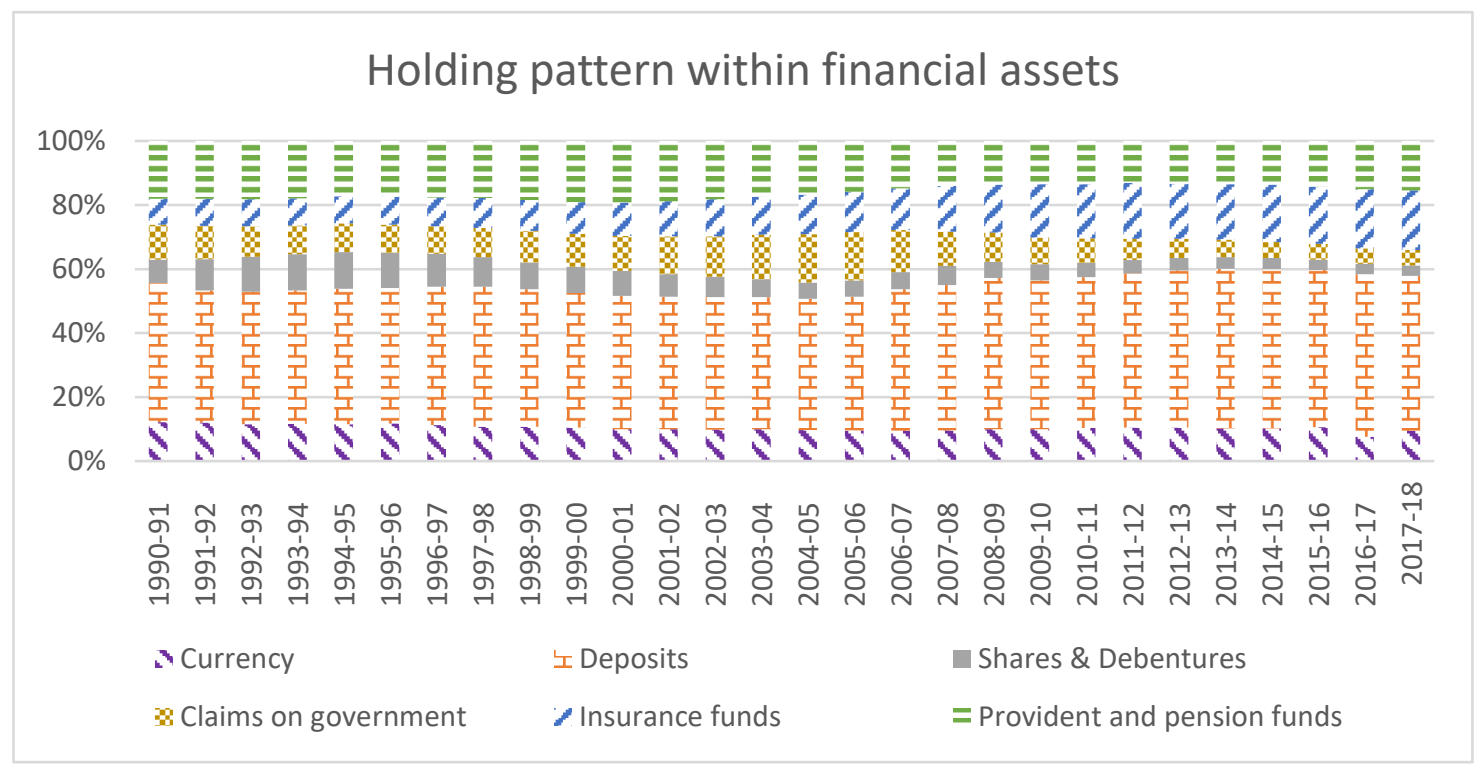

Figure 7. Structure of Financial Asset ownership for households

\footnotetext{
9 The asset position for 'Provident and Pension funds' is estimated from entitlements relating to funded retirement benefits for governments sector and non-government sector employees (RBI, 2018).

10 'Shares and Debentures' include investment in shares and debentures of credit / non-credit societies and investment in mutual funds.
} 


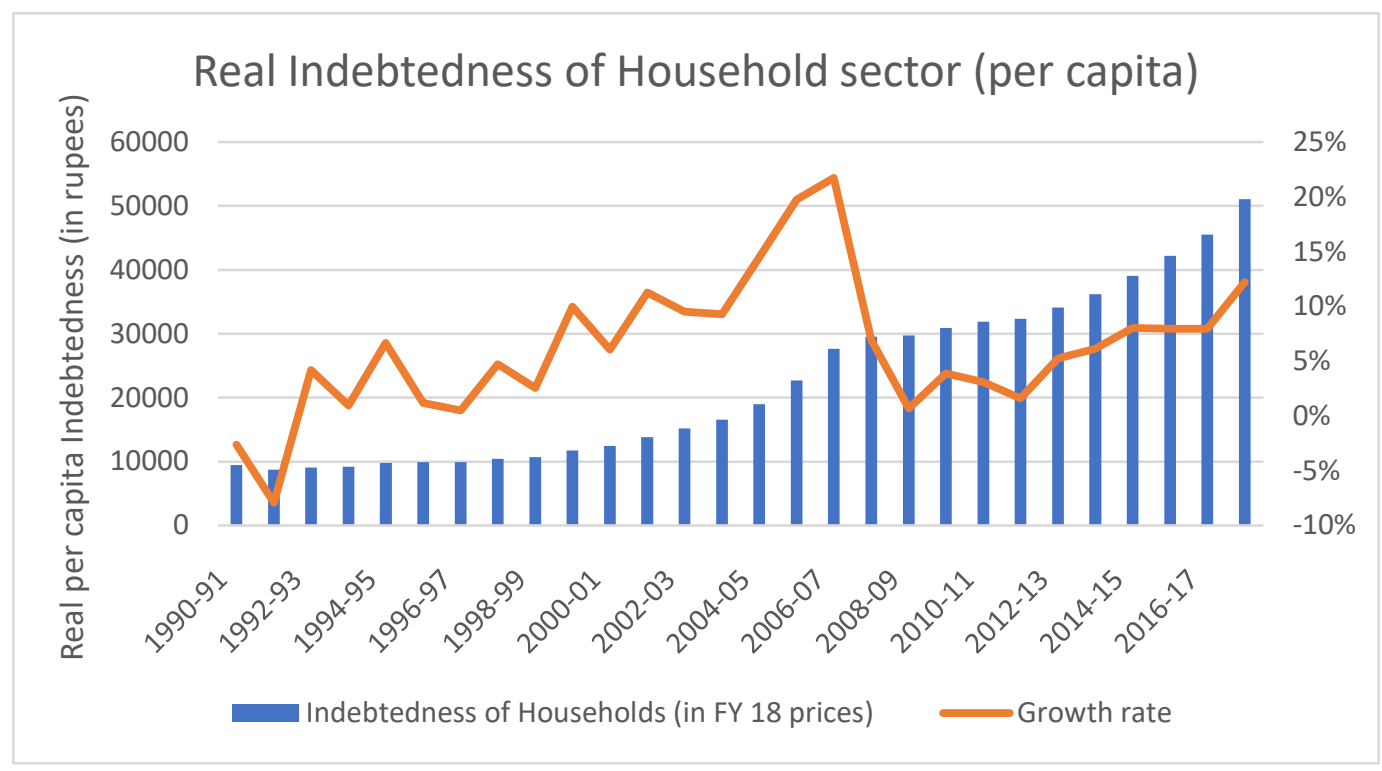

Figure 8. Evolution of Household Indebtedness

As per our HBS estimates in Table 1, the stock of total financial liabilities or indebtedness of the household sector has risen significantly over time (in nominal terms) from ₹1.4 trillion in 1990-91 to ₹67.2 trillion in 2017-18. In per capita terms, the real indebtedness of Indian household sector has risen from ₹9,460 in 1990-91 to ₹51,082 in 2017-18. However, the rate of growth of indebtedness has fluctuated wildly over time with a huge spike in the period building up to the global financial crisis of 2008 and a pronounced fall thereafter as depicted in Fig. 8.

The structure of household financing (from institutional sources) has changed over time as reflected in Fig. 9, with loans from cooperative non-credit societies and government vanishing almost completely from HBS and Bank loans dominating even more. Commercial banks and cooperative banks and societies remain the preferred credit institution for Indian households with the share of bank advances ${ }^{11}$ varying in the range of $80 \%-90 \%$ in total household debt. However, in the last five years or so, other financial institutions ${ }^{12}$ (such as NBFCs) - whose share have risen from $7.6 \%$ in FY14 to $16.4 \%$ in FY18 - have snatched some share of household debt from traditional banks - with their

\footnotetext{
11 'Bank advances' includes advances by banks and co-operative banks \& societies.

12 'Loans and advances from other financial institutions' includes advances by financial corporations \& non-banking companies and insurance corporations.
} 
share falling from $91.7 \%$ to $83.2 \%$ between $2013-14$ and $2017-18$. In the context of Indian Household Finance, there exists a complementarity between the banking sector and non-banking financial companies in their financial intermediation roles, which was also reported by RBI (2019). As evident from Fig. 9, the periods in which the share of loans and advances from banks rose $(83.3 \%$ to $91.7 \%$ between FY04 - FY13), the share of other financial institutions declined (13\% in FY04 to 7.6\% in FY13), and vice-versa between FY14 - FY18.

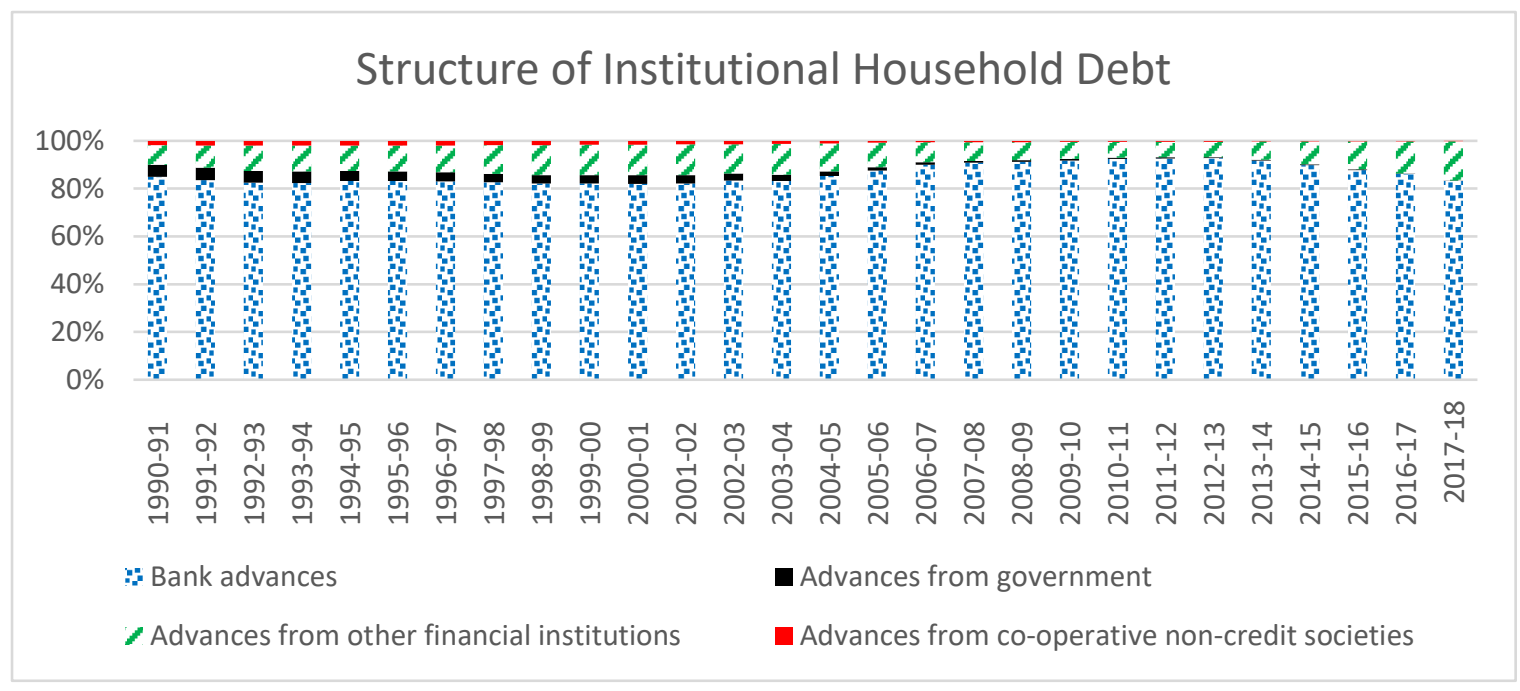

Figure 9. Evolution of composition of Household Debt from institutional sources

\subsection{Comparison with other estimates of India's HBS}

Historically, the preferred estimate of balance sheet for Indian households has been All India Debt and Investment Survey which is carried out every 10 years, the most recent round being the 2012round (NSSO, 2013). Apart from the long gaps in data release, household wealth surveys are generally not a reliable source for estimating wealth levels due to sampling and non-sampling errors which get magnified in the case of countries with high wealth inequality, such as India. The high skewness of wealth distribution makes sampling error more pronounced. Further, the non-sampling errors, 
arising due to differential response rates $^{13}$ and under-reporting ${ }^{14}$, make it difficult to extract an accurate representation of the upper tail of wealth distribution-where the bulk of wealth lies in the case of unequal societies. Consequently, household surveys usually produce lower wealth totals, especially in the case of financial assets and liabilities, when compared with the HBS data (Shorrocks et al., 2019).

Since 2010, Credit Suisse Research Institute has been publishing Global Wealth Databook annually which contains estimates of global household wealth covering all regions and countries. The most recent edition, GWD 2019, puts total net wealth (financial plus non-financial, net of total liabilities) owned by Indian households at ₹875 trillion $^{15}$ (Shorrocks et al., 2019). As compared to the HBS compiled in this paper, GWD 2019 underestimates household gross financial wealth by around 50\% from 2000-01 to 2009-10. The estimates provided by GWD 2019 converges after 2010-11 and reaches the vicinity of the computed HBS series in the last two years of the analysis period (see Fig. 10 and Table 2). However, the GWD 2018 severely underestimates gross financial wealth owned by Indian households, by $72 \%$ on an average, for all the years reported (see Fig. 10 and Table 2). The reason behind this discrepancy between the two editions is the change in methodology for estimating Indian household financial wealth by the authors of the Global Wealth Databook while advancing from 2018 to 2019 edition. The authors of GWD create an econometric model (elucidated in Davies et al., 2017) of per capita wealth using data from countries with HBS or survey data in at least one year and use this model to estimate per capita wealth levels in countries lacking direct data on household wealth; separate regressions are run for financial assets, non-financial assets and liabilities. In the model, a dummy is included for cases where the data source is a survey instead of HBS. The coefficient of this

\footnotetext{
${ }^{13}$ Wealthier households are less likely to participate in survey.

${ }^{14}$ Households are likely to under-report their financial assets and liabilities.

${ }^{15}$ Estimate as of mid-2019.
} 
dummy has been reported as negative and highly significant in the regression for financial assets (Shorrocks et al., 2018 and 2019), indicating that the average levels of financial assets tend to be much lower when the data is derived from a survey rather than HBS.

Table 2: Estimates of Gross Financial Wealth (in trillion rupees, current prices)

\begin{tabular}{|c|c|c|c|c|}
\hline Fiscal Year & HBS (Author's estimate) & GWD 2019 estimate & GWD 2018 estimate ${ }^{17}$ & RBI (2019) estimate $^{18}$ \\
\hline $2000-01$ & 19.3 & 9.7 & 1.6 & \\
\hline $2001-02$ & 22.1 & 9.8 & 7.6 & \\
\hline $2002-03$ & 25.4 & 12.3 & 9.6 & \\
\hline $2003-04$ & 29.3 & 15.2 & 11.5 & \\
\hline $2004-05$ & 33.7 & 16.6 & 12.7 & \\
\hline $2005-06$ & 39.6 & 19.0 & 16.3 & \\
\hline $2006-07$ & 47.2 & 18.5 & 19.4 & \\
\hline $2007-08$ & 54.9 & 29.7 & 16.2 & \\
\hline $2008-09$ & 62.2 & 30.8 & 14.1 & 105.7 \\
\hline $2009-10$ & 72.1 & 29.6 & 17.0 & 116.5 \\
\hline $2010-11$ & 82.9 & 47.9 & 23.9 & 129.6 \\
\hline $2011-12$ & 92.2 & 63.4 & 28.1 & 145.5 \\
\hline $2012-13$ & 102.9 & 75.4 & 29.2 & 161.6 \\
\hline $2013-14$ & 114.8 & 93.9 & 33.6 & 179.5 \\
\hline $2014-15$ & 127.4 & 98.7 & 38.0 & 202.6 \\
\hline $2015-16$ & 142.3 & 122.5 & 39.0 & \\
\hline $2016-17$ & 156.7 & 150.0 & 40.7 & \\
\hline $2017-18$ & 175.4 & 186.1 & & \\
\hline
\end{tabular}

All the editions before the 2019 edition of GWD, including GWD 2018, utilized All India Debt and Investment Survey data on financial assets owned by Indian households, which was adjusted upwards using the coefficient of dummy, to get an estimate of gross financial wealth in the survey year. For all years, except the survey year, the final totals are arrived upon by making forward projections based on estimated relationships between asset/debt totals and variables like house price indexes,

\footnotetext{
${ }^{16}$ Source: Shorrocks et al. (2019); for FY01-FY17, the tabulated data represents the outstanding stock on 31st December in the given fiscal year. For FY 18, the data represents average of stock on 31 Dec 2017 and 30 June 2018.

17 Source: Shorrocks et al. (2018); for FY01-FY16, the tabulated data represents the outstanding stock on 31st December in the given fiscal year, for FY 17, the data represents average of outstanding stock on 31st Dec 2016 and 30 June 2017 and for FY 18, the data represents stock on 30 June 2018.

18 Source: RBI (2019)

- The relative change in stock of financial assets (and liabilities, as reported in Table 4) between 2000-01 and 2001-02 appears to be unrealistic. GWD (2018) use adjusted survey means from the last two AIDIS rounds, viz. 2002 and 2012 , and accordingly extrapolate the data for the remaining years in the sample. It seems that the methodology employed in GWD (2018) is producing spurious backcasts for years before 2002.
} 
market capitalization data and GDP per capita growth in preceding years. Shorrocks et al. (2019) argue that the above methodology leads to underestimation of financial wealth, primarily because of the under-reporting of owned financial assets by Indian households in its decennial wealth survey. Therefore, GWD 2019 employs a different methodology for estimating financial wealth owned by Indian households wherein the estimates are based on the econometric model from Davies et al. (2017), which was originally meant to be used in the case of countries lacking aggregate national data on financial assets.

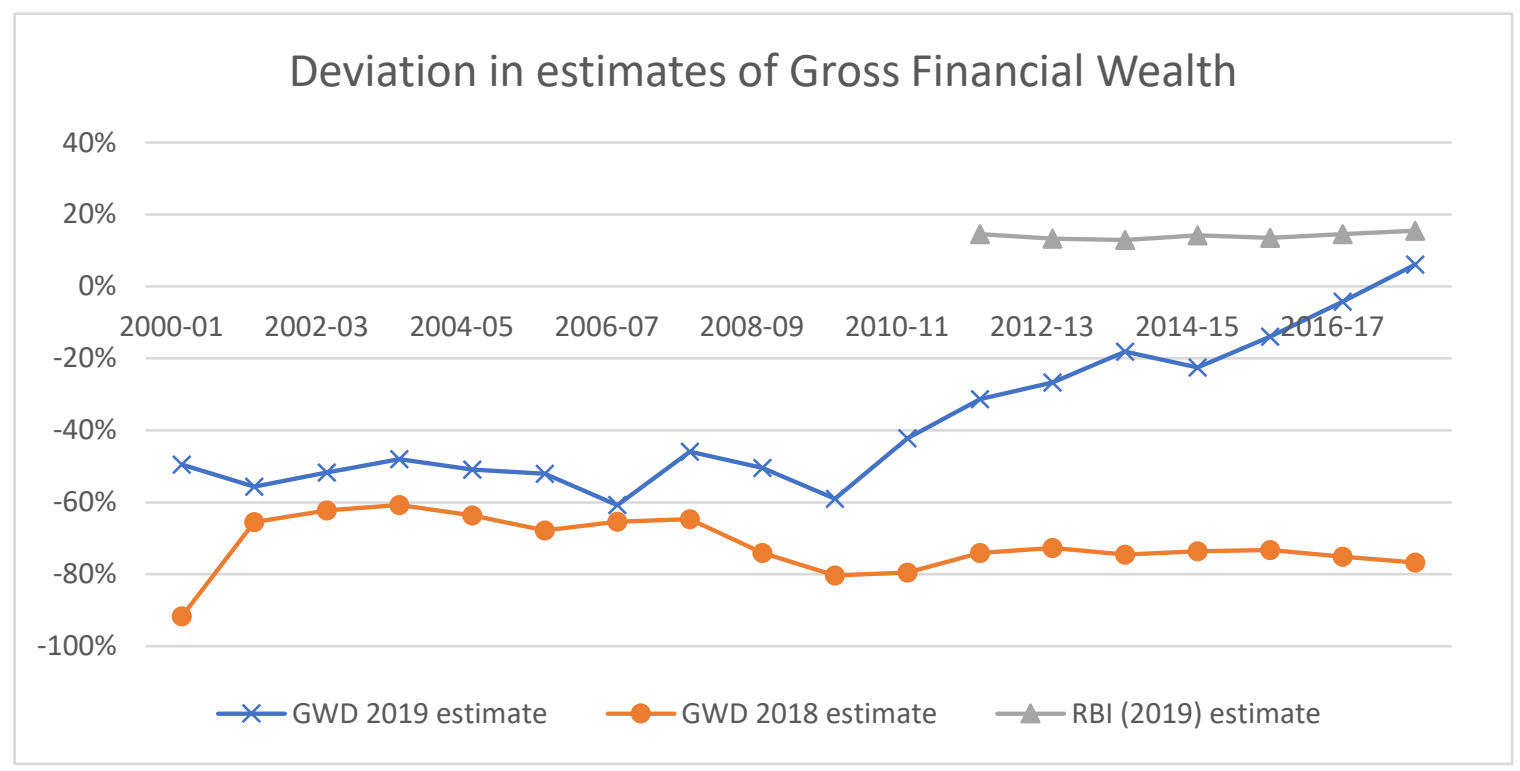

Figure 10. Deviation in estimates of stock of financial assets owned by households

The Reserve Bank of India recently released an estimate of Indian Household Balance Sheet along with RBI (2019) which consistently overestimates the stock of financial assets owned by Indian households, on an average by $14 \%$ when compared to the HBS compiled in this paper over the covered period of FY12 - FY18 (see Fig. 10 and Table 2). The FoF data reported with RBI (2019) incorporates changes due to transactions and revaluations; however, from the text it is not clear whether OCVAs are included in the flow data or not. To determine this, we compare the flow data reported in RBI (2019) with data available in National Accounts Statistics (NAS) and RBI (2017a). As apparent from Table 3, the changes in financial assets reported in RBI (2019) are consistently higher 
than those made available in NAS; the outcome is similar when RBI (2019) flow data is compared with that of RBI (2017a). Note that the minor discrepancy in RBI (2017a) and NAS FoF data (which has been used for compilation of HBS presented in this paper) is due to the fact that when released in 2017, the best estimates available with RBI (2017a) were $1^{\text {st }}$ and $2^{\text {nd }}$ revised estimates for FY16 and FY15 respectively. NSC (2018) found some unavoidable statistical discrepancies between FoF accounts compiled by the RBI and the financial accounts released by the CSO, however, the report noted that these discrepancies were not significant in the case of the household sector (ibid, p. 65). If we compare the flow data for FY14, the year for which final estimates are available in both NAS and RBI (2017a), it becomes clear that the RBI (2019) flow data is significantly higher (by 10\%) than the official number reported in the NAS-which is also equal to the number reported in RBI (2017a).

Table 3: Estimates of Change in Financial assets (in billion rupees)

\begin{tabular}{|l|l|l|l|l|l|l|}
\hline Source / Fiscal Year & \multicolumn{1}{|c|}{$2012-13$} & \multicolumn{1}{|c|}{$2013-14$} & \multicolumn{1}{|c|}{$2014-15$} & \multicolumn{1}{|c|}{$2015-16$} & $2016-17$ & $2017-18$ \\
\hline RBI (2019) & 10853 & 13053 & 15856 & 16110 & 17946 & 23060 \\
\hline RBI (2017a) & & 11908 & $12826^{\#}$ & $15142^{@}$ & & \\
\hline NAS & 10640 & 11908 & 12572 & $14962^{\phi}$ & $14384^{\#}$ & $18696^{@}$ \\
\hline
\end{tabular}

The methodology for compilation of the FoF accounts, as listed in RBI (2015), indicates that the Indian FoF accounts published by RBI do incorporate OCVA, apart from revaluations and transactions, and the same was confirmed by the author via personal correspondence with Reserve Bank of India under Right to Information Act, 2005. By definition, OCVA include changes in values due to unanticipated or unintentional volume changes that are not related to transactions or revaluation (IMF, 2011). OCVAs occur due to reasons related to economic appearance and disappearance of assets,

\footnotetext{
$\phi$ Third revised estimate at the time of publication

\# Second revised estimate at the time of publication

@ First Revised Estimate at the time of publication
} 
reclassifications and external events such as debt write-offs, wars or catastrophes (SNA, 2008). Some common examples of OCVAs related to financial assets are:

i. Liquidations or Bankruptcy: When an investor (creditor) recognizes that a financial claim can no longer be collected because of bankruptcy, liquidation or other factors, that claim is removed from his/her balance sheet ${ }^{19}$.

ii. Uncompensated seizures: When a government decides to nationalize/seize certain industries/assets within its jurisdiction without compensation, then the equity/asset position is extinguished through a volume change.

iii. Destruction of currency notes or bearer securities: As a result of a natural catastrophe or political events.

iv. Reclassification: Changes in volume of assets due to changes in demographic assumptions in the case of insurance and pension schemes (Daniele, 2017). Migration of persons can also result in reclassification of assets-if a household moves from one economy to another, taking its possessions (including financial assets) with it, they are recorded as OCVAs (SNA, 2008). Reclassification of an entire unit of NPISH (non-profit institutions serving households) can occur, probably into an NPI (non-profit institutions) serving some other sector of the economy and vice versa-assets and liabilities of the said NPI will be transferred to the disembarking sector of the economy.

The above-mentioned examples indicate that OCVAs have mostly diminishing effects on the stock of financial assets and therefore, it is likely that flows which include OCVAs will tend to be smaller than flows which omit the same. If the differences observed in Table 3 are viewed in the same context, it

\footnotetext{
${ }^{19}$ The corresponding liability must also be removed from the balance sheet of the debtor to maintain balance in the accounts of the total economy (SNA, 2008).
} 
leads us to infer that the OCVAs have not been incorporated into the flow data reported with RBI (2019) and this omission appears to be the primary reason for the deviation in financial wealth observed in Fig. 10 and Table 2.

\subsection{Household Indebtedness in India}

The risks associated with the household indebtedness could be judged by comparing the stock of debt to stock of assets or flow of income. The liabilities-to-household disposable income ratio, which is a fundamental measure of the debt repayment capacity of households, has direct application in the assessment of default risks and solvency of the household sector (Li, 2018). The financial soundness of the household sector can also be assessed by liabilities-to-financial assets ratio which is a better measure of risk assessment than liabilities-to-assets ratio, which also includes nonfinancial assets in the calculation. Non-financial assets, except gold, are plagued with liquidity risks mainly due to high trading costs, as in the case of real estate, and Akerlof's "lemon law" of information asymmetry, as observed in the market of consumer durables such as automobiles. A still better measure of household liquidity is the ratio of outstanding household debt-to-liquid assets, wherein liquid assets comprise of currency and deposits. Both currency and deposits can be liquidated in an event of financial distress without any significant loss of value ${ }^{20}$, unlike equities and debt securities whose value can plunge during a fire sale or market crash, or unlike pension and insurance funds which have liquidation restrictions.

By all measures, the Indian household sector has been in an upward leveraging cycle beginning from the period building up to the global financial crisis and has remained at higher levels since then (see Fig. 11). The increasing debt-to-income ratio in recent years is certainly a cause of worry about the

\footnotetext{
${ }^{20}$ Typically, Indian banks allow premature withdrawal of time deposits with a penalty in the range of $0.5 \%$ and $1 \%$ on the interest rate.
} 
sustainability of household debt given the possibility that households might be accumulating debt for supporting consumption - which has risen at a faster pace than disposable income in every year since FY 2010-11. A similar picture of worsening household balance sheet emerges from the perspective of liabilities-to-financial assets ratio, which has been rising in the last 15 years after a decade of balance sheet consolidation in the 1990s. Notice that this worsening of the household balance sheet was also observed in Fig. 2, which showed a significant dip in the rate of financial wealth accumulation after the financial crisis of 2008.

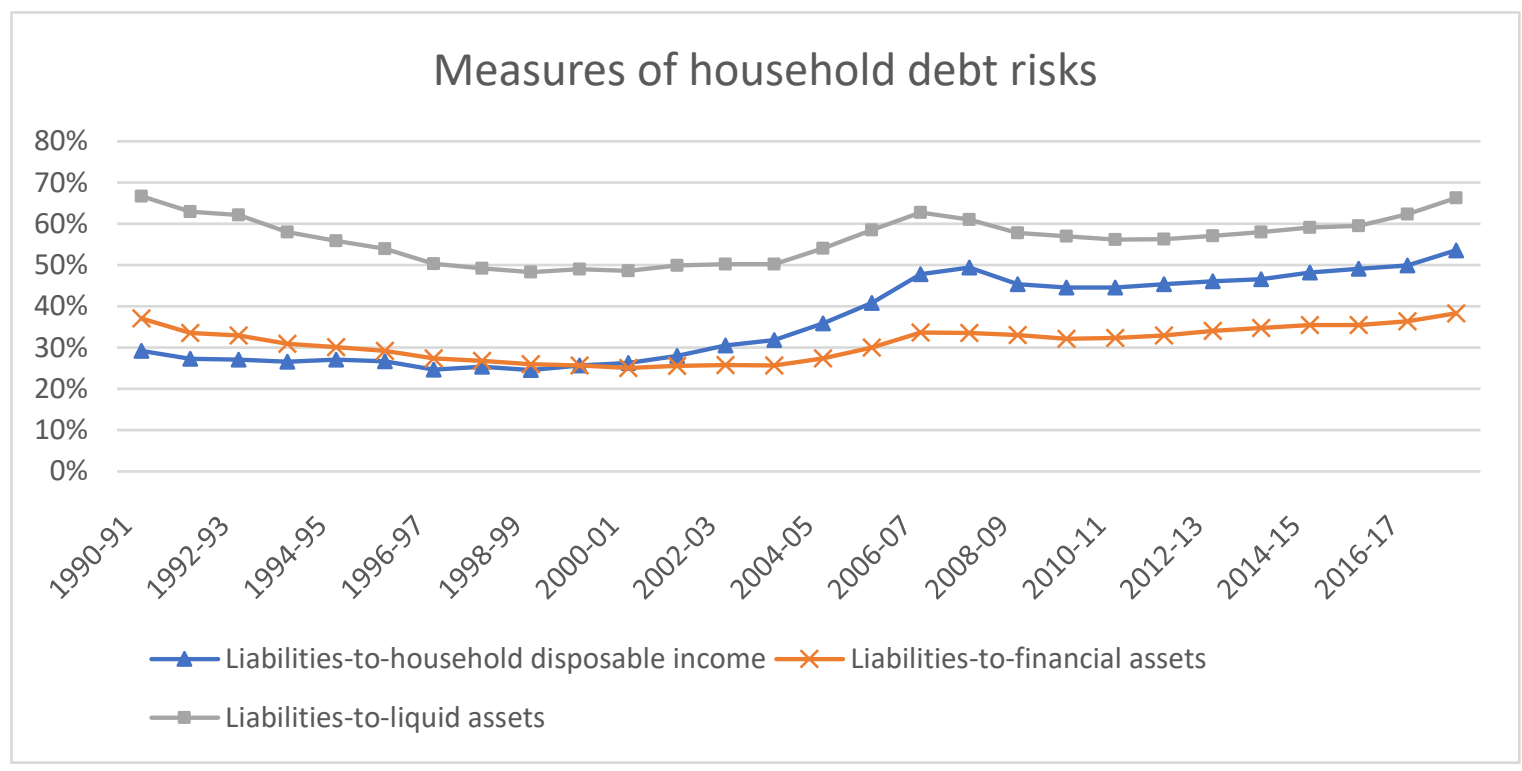

Figure 11. Evolution of risk measures of household debt

It would be interesting to compare our estimates of household indebtedness with estimates from decennial rounds of AIDIS and other subsequent estimates derived from it. As apparent from Table 4 and Fig. 12, our estimates of total household indebtedness are fairly large than those of AIDIS (by order of 2 or 3). This is possibly due to two main reasons: first, the differences in the definition of 'household'. As explained in Section 2, we have followed the CSO (2012) definition of household while constructing the balance sheet, which includes individuals, unincorporated establishments, nonprofit institutions serving households and all non-government non-corporate enterprises, whereas, AIDIS definition of 'household' draws from the concept of a common kitchen and is very similar to 
SNA (2008) interpretation of what constitutes a household. To be precise, AIDIS considers 'household' to be "a group of persons normally living together and taking food from a common kitchen" (NSSO, 2013), thus excluding NPISHs and quasi-corporations of business households. Technically, the size of the household sector as per the CSO (2012) definition would be larger than the size of the household sector arrived from AIDIS definition, and hence the tendency to produce larger estimates of household debt (or assets). Secondly, it is entirely possible that AIDIS is underestimating household indebtedness for various reasons, especially in rural areas, as have been accused of repeatedly by researchers (Gothoskar, 1988; Prabhu et al., 1988; Rao \& Tripathi, 2001; Chavan, 2012). Rao \& Tripathi (2001) blames this underestimation on the method of sampling and reduction in the sample sizes of villages and households. Bell (1990) argues that an increase in the State sample as compared to the Central sample has adversely affected the quality of AIDIS data as the State government agencies are less equipped in undertaking surveys than NSSO. Chavan (2012) shows that AIDIS underestimates rural household debt from commercial banks by about $46 \%$ in 1991 round and by around 35\% in the 2002 round. Rajkumar et al. (2019) have compiled a supply-side estimate of institutional household debt which includes outstanding credit to individuals for different occupational activities, personal loans, professional services and all small borrowal accounts from commercial banks and cooperative banks and societies.

When compared with either Rajkumar et al. (2019) or estimates reported in this paper, the AIDIS underestimates household debt owed to banks and cooperatives at the all-India level by roughly the same factor ( 70\%) over the last four rounds of survey (see Table 5). Rajkumar et al. (2019) also criticize the RBI supply-side data on household institutional credit, which we have used to construct HBS in this paper and infer that there are substantial margins of errors on both the supply-side (from RBI data) and demand-side (from AIDIS data) estimates. 
Table 4: Estimates of total household debt (in billion rupees, current prices)

\begin{tabular}{|r|r|r|r|r|r|}
\hline Fiscal Year & $\begin{array}{r}\text { HBS (Author's } \\
\text { estimate) }\end{array}$ & $\begin{array}{r}\text { AIDIS } \\
\text { estimate }^{21}\end{array}$ & $\begin{array}{l}\text { GWD 2019 } \\
\text { estimate }^{16}\end{array}$ & $\begin{array}{l}\text { GWD 2018 } \\
\text { estimate }^{17}\end{array}$ & $\begin{array}{l}\text { RBI (2019) } \\
\text { estimate }^{22}\end{array}$ \\
\hline $1980-81$ & 288 & 92 & & & \\
\hline $1990-91$ & 1401 & 373 & & & \\
\hline $2000-01$ & 4833 & & 2653 & $2653^{\bullet}$ & \\
\hline $2001-02$ & 5664 & 1768 & 2926 & 1676 & \\
\hline $2002-03$ & 6532 & & 4064 & 2310 & \\
\hline $2003-04$ & 7525 & & 4907 & 2751 & \\
\hline $2004-05$ & 9252 & & 6068 & 3327 & \\
\hline $2005-06$ & 11885 & & 6786 & 3869 & \\
\hline $2006-07$ & 15910 & & 6625 & 4966 & \\
\hline $2007-08$ & 18451 & & 11366 & 6087 & \\
\hline $2008-09$ & 20568 & & 12492 & 5703 & \\
\hline $2009-10$ & 23189 & & 11980 & 7490 & \\
\hline $2010-11$ & 26779 & & 21208 & 8971 & \\
\hline $2011-12$ & 30431 & 12163 & 28207 & 12636 & 24790 \\
\hline $2012-13$ & 35001 & & 33425 & 15920 & 28123 \\
\hline $2013-14$ & 39961 & & 39465 & 19348 & 31729 \\
\hline $2014-15$ & 45172 & & 40611 & 24666 & 35521 \\
\hline $2015-16$ & 50502 & & 49701 & 32451 & 39468 \\
\hline $2016-17$ & 56983 & & 56731 & 38745 & 43279 \\
\hline $2017-18$ & 67225 & & 70029 & 48587 & 50743 \\
\hline
\end{tabular}

\section{Deviation in estimates of total household debt}

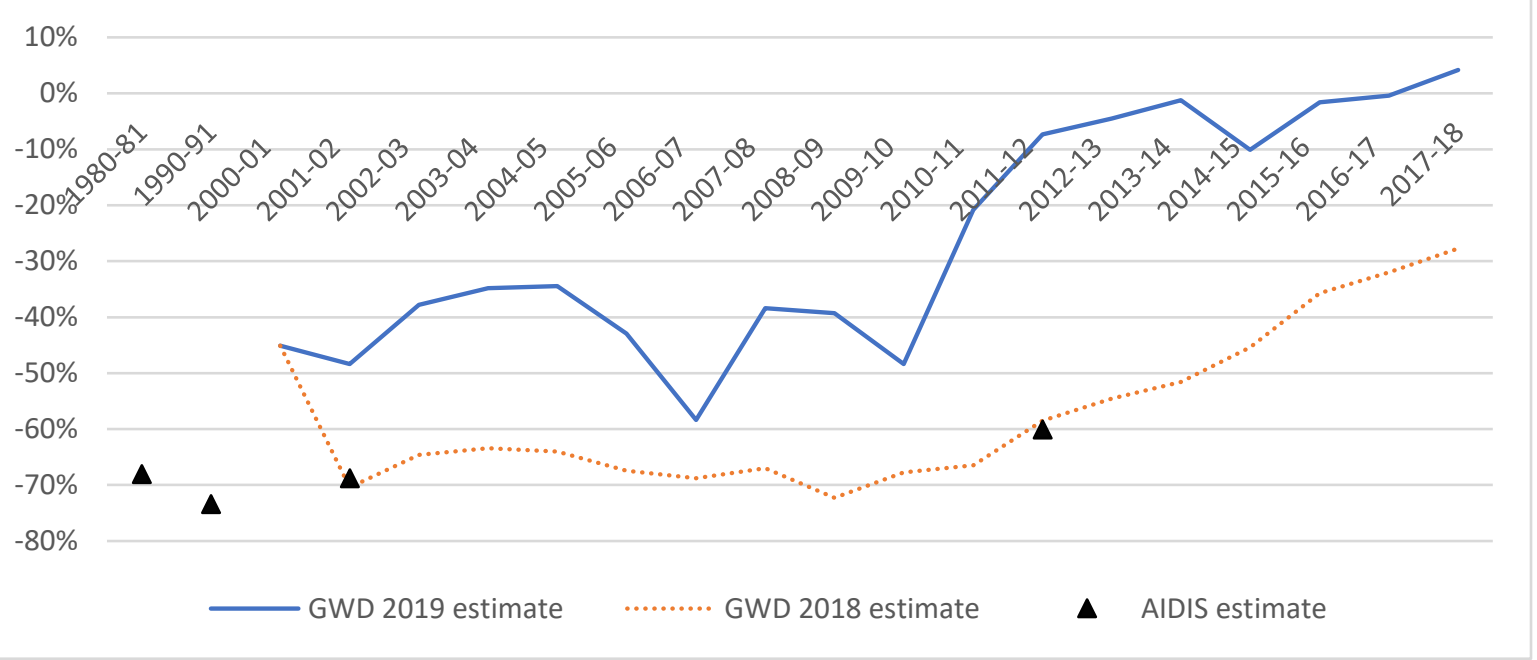

Figure 12. Deviation in estimates of stock of total debt owed by households

\footnotetext{
${ }^{21}$ Source: last four rounds of AIDIS, viz., 1981, 1991, 2002 and 2012. The AIDIS data represents the value of stock on $30^{\text {th }}$ June of the corresponding year. We approximate the stock of debt at the end of a fiscal year with household debt reported in AIDIS of the corresponding year; for example, the household debt reported in 1991 AIDIS is ascribed to stock at the end of FY91.

${ }^{22}$ Source: RBI (2019); the reported data includes only institutional household debt.
} 
Table 5: Estimates of household debt owed to banks and cooperatives (in bn rupees)

\begin{tabular}{|l|r|r|r|r|}
\hline \multicolumn{1}{|c|}{ Source / Year } & \multicolumn{1}{|c|}{1981} & 1991 & 2002 & \multicolumn{1}{c|}{2012} \\
\hline AIDIS estimate $^{23}$ & 47 & 182 & 905 & 7852 \\
\hline HBS (Author's estimate) ${ }^{24}$ & 145 & 791 & 2964 & 20401 \\
\hline Rajkumar et al. (2019) estimate & 135 & 684 & 3310 & 19926 \\
\hline
\end{tabular}

But in my opinion, the supply-side household credit data collected from various banks and financial institutions are more reliable than AIDIS data collected directly from households, after correcting for the "true" size of the household sector. It is justified to assume that debt is recorded accurately in the accounting books of banks and other financial institutions, whereas the outstanding stock of debt reported by households at the time of survey might be affected by memory lapse problem due to which the respondent may fail to recollect the exact details (such as interest rates and maturity period) of outstanding loans which were raised way back in the past. Even if these details are known, correct calculation of principal and interest outstanding is needed from either the respondent or the surveyor to arrive at a reliable estimate of total debt outstanding; banks are well-versed in such calculations. Moreover, it is important to keep in mind that debt is a sensitive issue in Indian society, and therefore, it is highly possible that some households might be underreporting the levels of debt owed and causing a downward bias in the AIDIS estimates (Shorrocks et al., 2019).

The estimates of household debt provided by Credit Suisse Global Wealth Databook (GWD) includes both institutional and non-institutional debt and are derived from AIDIS. Notice that GWD 2018 estimates are fairly close to AIDIS estimate of household debt (see Fig. 12 and Table 4). GWD 2019 estimates of household debt, on the other hand diverged significantly (by $-40 \%$ on an average) from HBS estimates presented here between FY01 - FY11 but in the recent times the estimates from GWD 2019 have come pretty close to HBS estimates (see Fig. 12 and Table 4), with the average deviation

\footnotetext{
${ }^{23}$ Source: AIDIS rounds; the AIDIS data represents the value of stock on $30^{\text {th }}$ June of the corresponding year.

${ }^{24}$ Source: Author calculations; the data represents the value of stock on $31^{\text {st }}$ March of the corresponding year.
} 
between the two estimates falling to $-3 \%$ for the FY12 - FY18 period. The primary methodological difference between the two editions of GWD is that GWD 2018 uses raw AIDIS data on household debt (Shorrocks et al., 2018) whereas, GWD 2019 acknowledges the under-reporting of household debt in AIDIS and therefore, corrects the survey estimate of the debt level in India using a consensus factor from the literature (Shorrocks et al., 2019).

The stock data released along with RBI (2019) and as reported in Table 4, includes only institutional household debt and therefore cannot be directly compared with HBS figures reported in Table 4 which includes both institutional and non-institutional debt. Fig. 13 shows that RBI (2019) overestimates the stock of institutional financial liabilities over the covered period of FY12 - FY18, although to a lesser extent than was observed with financial assets in Fig. 10, and the deviation between the two estimates is shrinking over time. The reason for this overestimation of debt appears similar to that inferred for financial assets-the omission of OCVAs from flow data that has been used to compile stock data reported along with RBI (2019). If we compare the RBI (2019) flow data with those made available in NAS and RBI (2017a), we observe that the changes in financial liabilities reported in $\mathrm{RBI}$ (2019) are most of the times ${ }^{25}$ higher than those reported in the other two sources (see Table 6).

In the context of debt, the most relevant OCVAs are debt write-offs and write-downs which involve unilateral reductions by a creditor of the amount owed to $\mathrm{it}^{26}$. This usually occurs when a creditor concludes that a debt obligation has no or a reduced value because entire or a part of the debt shall not be paid back because of debtor's insolvency or other reasons. In such cases, the financial asset is removed from the balance sheet of the creditor and the corresponding liability is removed from the

\footnotetext{
${ }^{25} \mathrm{~A}$ possible reason for reversal in the sign of deviation could be the revision of estimates in National Accounts at the time of publication.

${ }^{26}$ Note that these are different from debt forgiveness, which is a mutual agreement, and is therefore classified as a transaction.
} 
balance sheet of the debtor through other changes in the volume of assets (IMF, 2014). OCVAs corresponding to debt write-offs or write-downs will tend to diminish the debtor's gross and net debt stock (IMF, 2011). This leads us to suspect that the OCVAs have not been incorporated into the Change in Financial Liabilities data reported with RBI (2019) and this omission appears to be the primary reason for the overestimation of institutional household debt by RBI (2019) as observed in

Fig. 13.

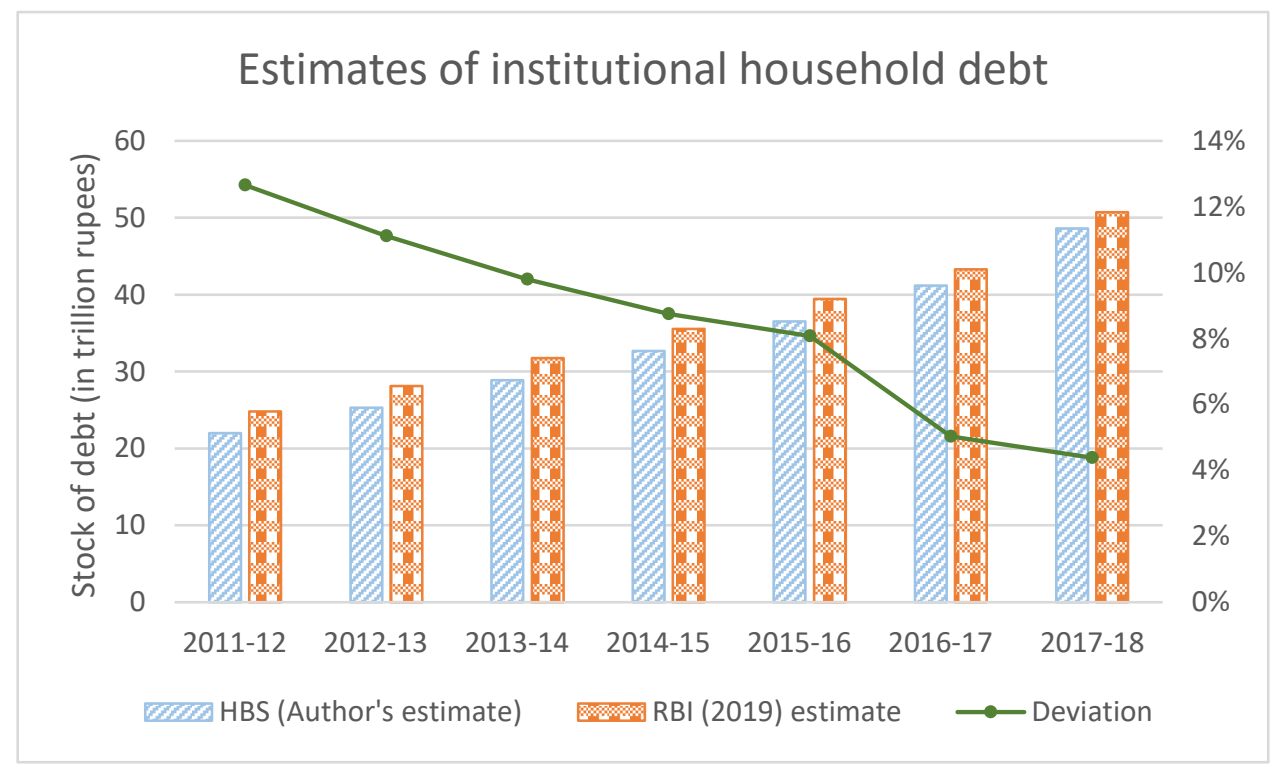

Figure 13. Estimates of household debt from institutional sources

Table 6: Estimates of Change in Institutional Financial Liabilities (in billion rupees)

\begin{tabular}{|c|l|l|l|l|l|l|}
\hline Source / Fiscal Year & $2012-13$ & $2013-14$ & $2014-15$ & $2015-16$ & $2016-17$ & $2017-18$ \\
\hline RBI (2019) & 3331 & 3606 & 3788 & 3942 & 3806 & 7450 \\
\hline RBI (2017a) & & 3587 & $3634^{\#}$ & $4318^{@}$ & & \\
\hline NAS & 3304 & 3587 & 3768 & $3854^{\phi}$ & $4686^{\#}$ & $7406^{@}$ \\
\hline
\end{tabular}

\footnotetext{
$\phi$ Third revised estimate at the time of publication.

\# Second revised estimate at the time of publication.

$@$ First revised estimate at the time of publication.
} 


\section{An International comparative analysis: Broad trends in}

\section{Household Finance}

In this article, we have not attempted to estimate the stock of non-financial assets owned by households, mainly due to the paucity of reliable flow/stock data for physical assets. However, the AIDIS data contains an estimate for non-financial assets as well. Based on the latest AIDIS data, RBI (2017b) notes that an average Indian household has $77 \%$ of its total assets in real estate, $11 \%$ in gold, $7 \%$ in other durable goods and just $5 \%$ in financial assets. Davies \& Shorrocks $(2000$, p. 630$)$ notice that wealth surveys, in general, do remarkably well for owner-occupied housing - which, as pointed out above, is the main component of non-financial assets in the case of India. Therefore, we accept the estimates of non-financial assets reported in GWD 2019-which are based on AIDIS data-as fairly reliable and use the same for the international comparative analyses presented below, by combining the estimates for non-financial assets reported in Shorrocks et al. (2019) with the estimates of financial assets and total liabilities compiled in this paper.

There appears to be a link between household debt level (as proportion of gross wealth) and the stage of economic development. As depicted in Fig. 14, household liabilities amount to $8 \%$ of gross wealth in India, $6 \%$ in China and $10 \%$ in Africa, but averages more than $13 \%$ in both North America and Europe ${ }^{27}$. The world average is close to $12 \%$. Globally, the wealth is majorly held in financial assets which make up $55 \%$ of gross wealth, while non-financial assets account for $45 \%$ of household wealth. In India, non-financial assets form the bulk of the household wealth, whereas financial assets account for only $20 \%$ of the wealth (see Fig. 14). This dominance of non-financial assets in India is anomalous even when we take into account the global pattern based on the stage of economic

\footnotetext{
${ }^{27}$ In this paper, countries are classified into geographical regions as per the United Nations Geoscheme of UNSD.
} 
development. In general, developing regions such as Latin America or Africa hold around $45 \%$ of their wealth in financial assets. Contrastingly, in the developed regions, such as North America, financial assets are relatively more important and constitute $72 \%$ of gross assets. Chinese households maintain $56 \%$ of their gross wealth in the form of financial assets. If we zoom in and look at the country-level composition of wealth, it becomes clear that there exists a direct relationship between the share of financial assets in the gross household wealth and the level of financial development in a country (as measured by the IMF Financial Development Index). Fig. 15 plots the 3-year average ${ }^{28}$ ratio of financial to non-financial assets versus 3-year average (2015-17) of financial development index value for select 27 countries $^{29}$. When compared to other countries with similar levels of financial development scores, such as Indonesia and Mexico, the share of non-financial assets in household wealth appears to be disproportionately high. However, there do exist other countries within the sample such as Sri Lanka, Iran, Turkey and Thailand which exhibit similar disproportionate shares of non-financial assets in relation to their respective levels of financial development.

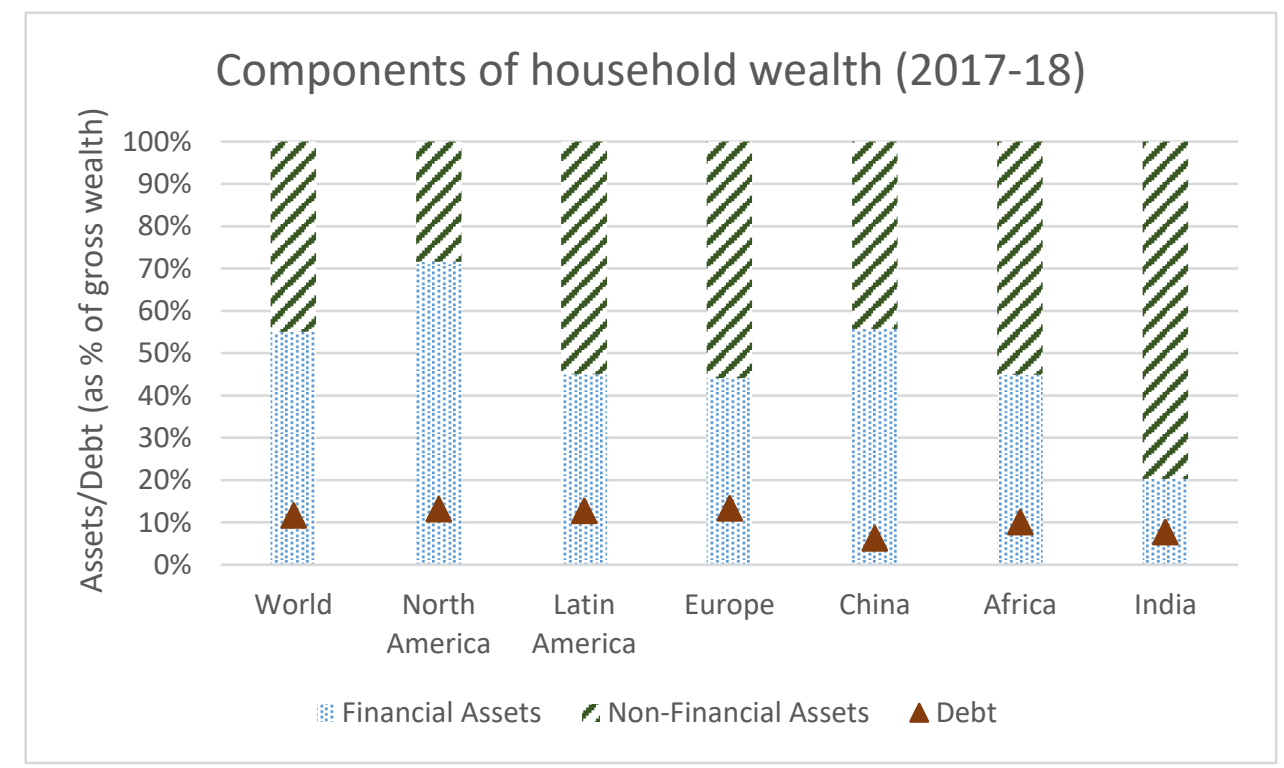

Figure 14. Components of household wealth by region Source: Author calculations and Shorrocks et al. (2019)

\footnotetext{
${ }^{28}$ The annual average of financial to non-financial assets ratio from 2015 to 2018 is taken for all countries, except for India-for which the average from FY 2015-16 to 2017-18 is considered.

29 The sample represents a mix of leading OECD economies, neighbouring states, and emerging economies whose performances are often presented as benchmarks in the Indian economic discourse.
} 


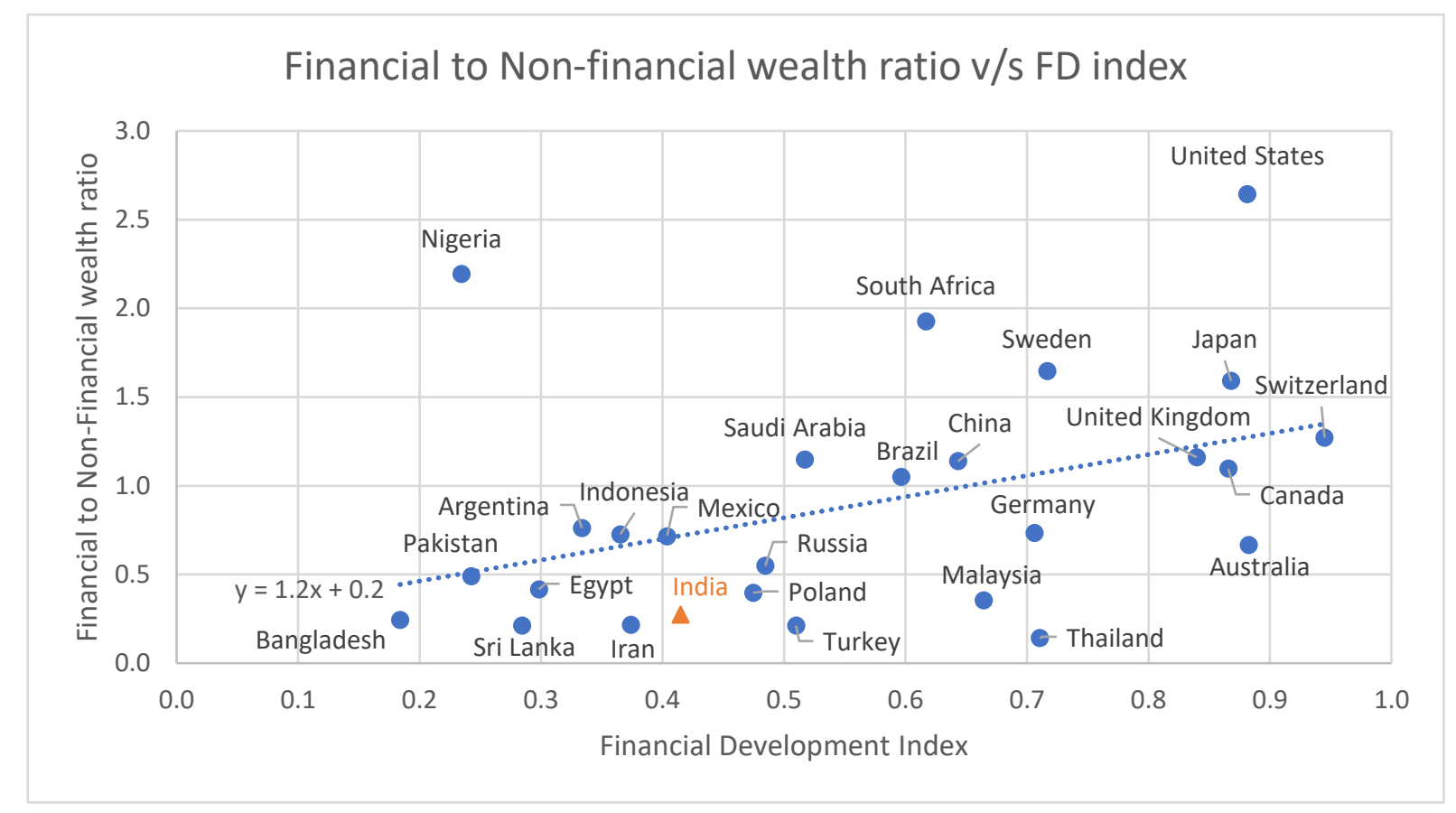

Figure 15. Financial to Non-financial assets ratio v/s Level of Financial Development Index for select countries. Source: Author calculations, IMF database and Shorrocks et al. (2019)

\section{Components of gross financial wealth}
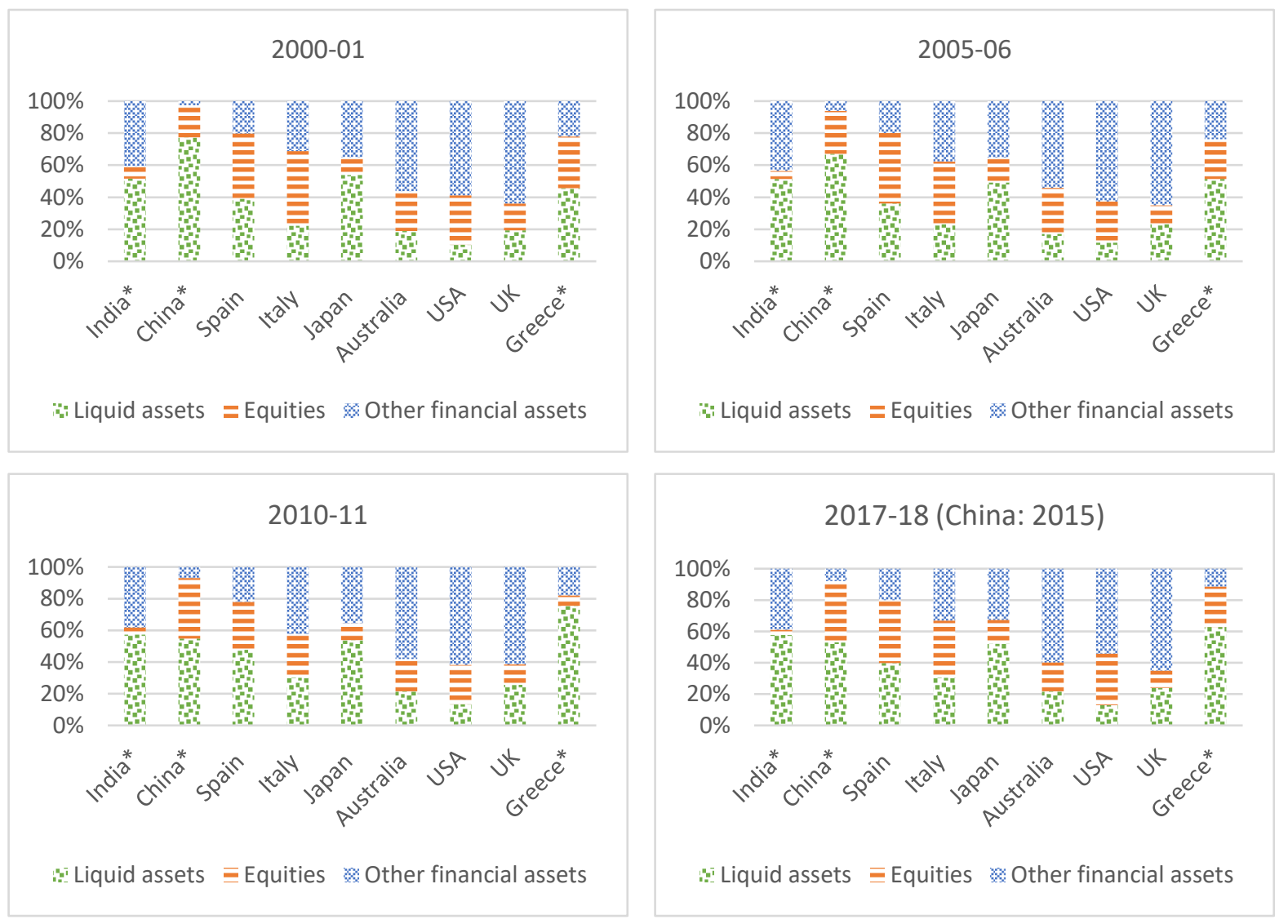

Figure 16. Evolution of composition of gross financial wealth in select economies (* implies emerging economy). Source: Author calculations, OECD.Stat, and Shorrocks et al. (2019). 
Fig. 16 shows the breakdown ${ }^{30}$ of gross financial wealth into three categories: liquid assets (currency and deposits); equities (defined ${ }^{31}$ as all shares and other equities directly owned by households); and other financial assets (which mainly comprise the reserves of life insurance companies and pension funds). Unlike the Chinese households-who have redistributed their portfolio away from liquid assets and towards equities over time, Indian households have maintained their preference for liquid assets. As per 2018 data, households, internationally on average, hold $37 \%$ of their financial wealth in liquid assets, $29 \%$ in equities and $34 \%$ in other financial assets (Shorrocks et al., 2019). All emerging ${ }^{32}$ market countries in our sample have the share of liquid assets higher than the global average. The relatively low share of directly held equities and a higher share of other financial assets observed in India is partly related to a systematic negative association between equities and other financial assets observed across countries in Fig. 16 and also reported by Shorrocks et al. (2019). Shorrocks et al. (2019) argue that in countries where private pension systems are highly developed, "other financial assets" may tend to crowd out privately-held equities. However, in my opinion, a unique set of factors might be at play in India; the bulk of Indian household savings categorized as "other financial assets" have gone primarily into Provident and Pension funds (48\% of all "other financial assets" in 2017-18), Life Insurance funds (40\%) and small savings scheme. Notably, all of these investment vehicles come with income tax exemptions and the majority have an either implicit or explicit sovereign guarantee. The two preferred investment instruments of the Indian middle class-Public Provident Fund (PPF) and small savings schemes-come with income tax exemptions, guaranteed interest rate and sovereign guarantee (net collections received in PPF and National Small

\footnotetext{
${ }^{30}$ For the cross-country analyses presented in this section, the author has attempted to create a fairly balanced mix of leading advanced and emerging economies. However, the reader might notice that the final set of countries chosen vary from analysis to analysis (refer Fig. 16, 18, and 19) primarily due to restrictions imposed by data availability, such as, lack of data on share of liquid assets in HBS of certain countries, etc.

${ }^{31}$ Due to data restrictions, equities in the case of India include shares and debentures directly held by households.

32 In this article, economies are designated as 'emerging' based on the list of EM countries included in MSCI Emerging Markets Index (Apr 2020 composition).
} 
Savings Fund are either invested in debt securities issued by central and state governments or lent to public agencies like Food Corporation of India and National Highways Authority of India, among others). Moreover, every salaried employee in India has to compulsorily contribute a defined portion of his income to Employee Provident Fund (EPF) and a matching sum is contributed to the fund by the employer as well. These contributions are exempt from income tax just like $401(\mathrm{k})$ in the US. However, the EPF is different from $401(\mathrm{k})$ in terms of the flexibility of choosing an investment fund that comes with $401(\mathrm{k})$ and the variability in returns that results from the performance of the chosen fund; the EPF is managed by a public agency - Employees' Provident Fund Organization (EPFO) - that offers a guaranteed return and is perceived as an extension of the government. In the case of insurance funds, the market is dominated by the Life Insurance Corporation of India (LIC), a stateowned corporation with more than $70 \%$ market share. Premiums paid towards life insurance policies enjoy income tax exemption up to a certain limit but more importantly, investing in LIC policies is considered safe due to explicit sovereign guarantee provided to policyholders under section 37 of the Life Insurance Corporation (LIC) Act passed in 1956 by the Indian parliament. Apparently, these sovereign guarantees, tax exemptions and fixed rates of return offered by most of the investment instruments making up "other financial assets" might be responsible for crowding out direct ownership of shares and debentures by Indian households, among other factors like preference towards currency and deposits.

Next, we scrutinise the financial soundness of the Indian household sector vis-à-vis households in other regions of the world. The first indicator we employ is the liabilities-to-assets ratio, which is a useful metric in gauging solvency risks embedded in any sector. As depicted in Fig. 17, the household debt (as \% of gross wealth) in India has remained below $10 \%$ over the whole sample period, barring the spike observed during the build-up and peak of the global financial crisis (GFC). For the world, as a whole, the household debt-to-wealth ratio rose from $13.4 \%$ in $2000-01$ to $15 \%$ in $2008-09$ and then 
subsequently declined to $11.8 \%$ in $2017-18$. Although the debt-to-wealth ratio for the Indian households has remained at modest levels compared to the world average during the sample period, the household debt (as \% of gross wealth) has not ebbed to pre-crisis levels even after ten years from the GFC, and have remained at somewhat relatively elevated levels. This story has played out even more prominently in other developing regions like Africa and Latin America. Household debt-towealth ratio in Africa has risen from $8.7 \%$ in $2000-01$ to reach a peak of $11.8 \%$ in $2011-12$, and thereafter settling near $10 \%$ levels in recent years. Similarly, household debt-to-wealth ratio in Latin America has ended up being risen by more than half over the sample period. The most striking rise in household debt (as \% of gross wealth) has been noted in China (see Fig. 17), where it has more than quadrupled from $1.4 \%$ in $2000-01$ to $6.3 \%$ in $2017-18$, with a peak of $7.6 \%$ coinciding with 2015 16 stock market crash in China. Although, developed regions such as North America and Europe, in general, have higher debt-to-wealth ratios than their developing counterparts, the households in these regions seem to have undergone a course of deleveraging post-GFC and have repaired their balance sheets to pre-crisis levels. In North America, household debt (as \% of gross wealth) rose from $14.2 \%$ in $2000-01$ to $20.1 \%$ in $2008-09$, but then came down to $13.2 \%$ in $2017-18$. A similar inverted V-shaped path was charted by European households over the sample period, as observed in Fig. 17.

A liquidity-adjusted measure of risk associated with household debt is liabilities-to-liquid assets ratio which addresses the concerns over the liquidity of non-financial and some other financial assets as discussed in Section 3.2. As depicted in Fig. 18, the outstanding stock of household debt has remained lower than the stock of liquid assets in all the emerging economies in our sample, except South Africa. The debt-to-liquid assets ratio for Indian households has risen from $49 \%$ in $2000-01$ to $66 \%$ in 2017 18. This climbing leverage ratio certainly poses a threat to the household debt sustainability in India but the threat is relatively tamed when compared to China, where the ratio has exploded from $5 \%$ in 2000-01 to $33 \%$ in 2017-18. China has witnessed a phase of rapid financial development in the last 
two decades -its FD index score rose from 0.43 to 0.64 between 2000 and 2017 - which has provided individuals and families more access to credit, especially to consumption credit and mortgage loans (amidst the boom in Chinese housing market). Moreover, the share of liquid assets in gross financial wealth held by Chinese households has fallen from $77 \%$ in 2000 to $53 \%$ in 2015, as depicted in Fig. 16. Indian households, on the other hand, have modestly increased their allocation in liquid assets from $52 \%$ in 2000 to $58 \%$ in 2017 and the development level of financial sector in the country has stagnated over the sample period - India started with an FD index score of 0.42 in 2000 and ended up with the same score in 2017. These factors have probably prevented a China-like eruption of household debt in India. Moving to households in other emerging economies, such as South Africa and Greece ${ }^{33}$, we observe these countries charting an inverted V-shaped path, peaking in 2007-08 (GFC) and 2012-13 (euro area crisis) respectively, and ending up at a higher household debt-to-liquid assets ratio at the end of the sample period in comparison to their 2000-01 figures. Developed economies like Australia, Italy and USA also follow an inverted V-shaped chart, peaking in 2007-08, but household in these economies consolidated their balance sheet post-GFC and ended up with a lower debt-to-liquid assets ratio in 2017-18 as compared to the numbers they had at the beginning of this millennium. Over the same period, Japanese households have significantly deleveraged by steadily reducing their debt-to-liquid assets ratio from $56 \%$ in $2000-01$ to $33 \%$ in $2017-18$.

Last but not the least, we look at the evolution of household debt-to-income ratio-a critical measure of debt servicing capacity of the households. Unlike advanced economies such as USA and Japan, the outstanding stock of total household debt for all the emerging economies in our sample, including India, has remained smaller than the flow of household disposable income (HDI) in any year of the sample period (see Fig. 19). The debt-to-HDI ratio has more than doubled from $26 \%$ in $2000-01$ to

\footnotetext{
${ }^{33}$ It might come as a surprise to some readers that Greece has remained an 'emerging' market, after being demoted to one from the 'developed' status in 2013.
} 
54\% in 2017-18, indicating a dire collapse in the debt servicing capacity of Indian households. A more frightful trend emerges in other emerging economies such as China and Mexico. The household debtto-income ratio has snowballed from $9 \%$ to $56 \%$ between $2000-01$ and $2016-17$ in China, whereas in Mexico it swelled from $7 \%$ in $2003-04$ to $38 \%$ in $2017-18$. However, this is not an emerging economy phenomenon; households in South Africa and Brazil have charted a path similar to their counterparts in the US, where the liabilities-to-income ratio reached a peak during the global financial crisis and then eventually fell back to the pre-crisis levels. In our sample, Japan is the only country that has systematically reduced its household debt-to-income ratio in the last two decades.

A general pattern of convergence is visible in Fig. 19 which shows that households in countries, where the debt-to HDI ratio was high (close to or greater than 100\%) at the beginning of the century, have improved their debt-servicing capacity whereas, countries which entered this century with a low household debt-to-income ratio have seen a general increase in the ratio and have come closer to the former set of countries in the recent years.

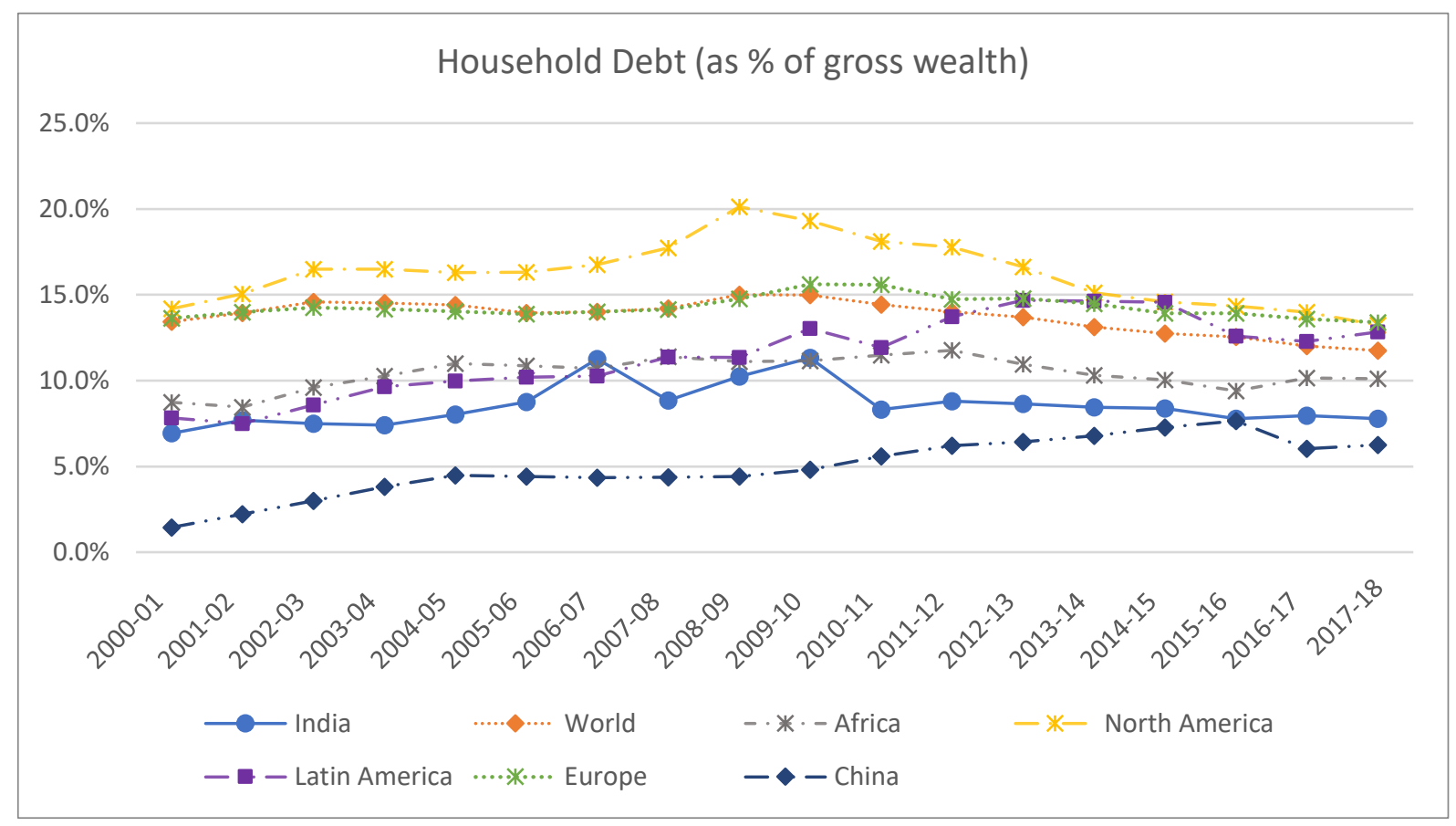

Figure 17. Evolution of household debt as proportion of gross wealth Source: Author calculations and Shorrocks et al. (2019) 


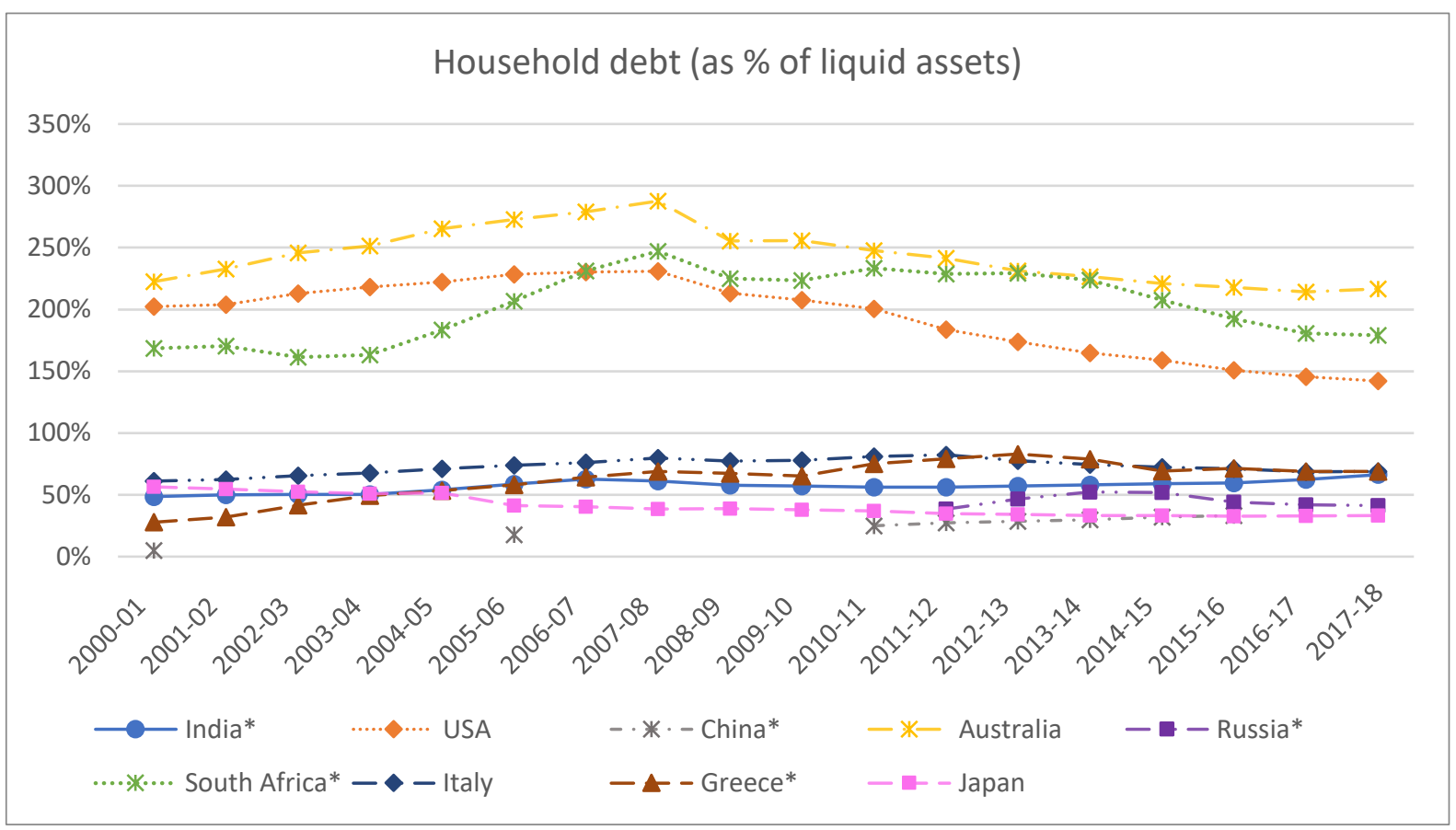

Figure 18. Evolution of household debt as proportion of liquid assets (* implies emerging economy). Source: Author calculations, OECD.Stat, and Shorrocks et al. (2019).

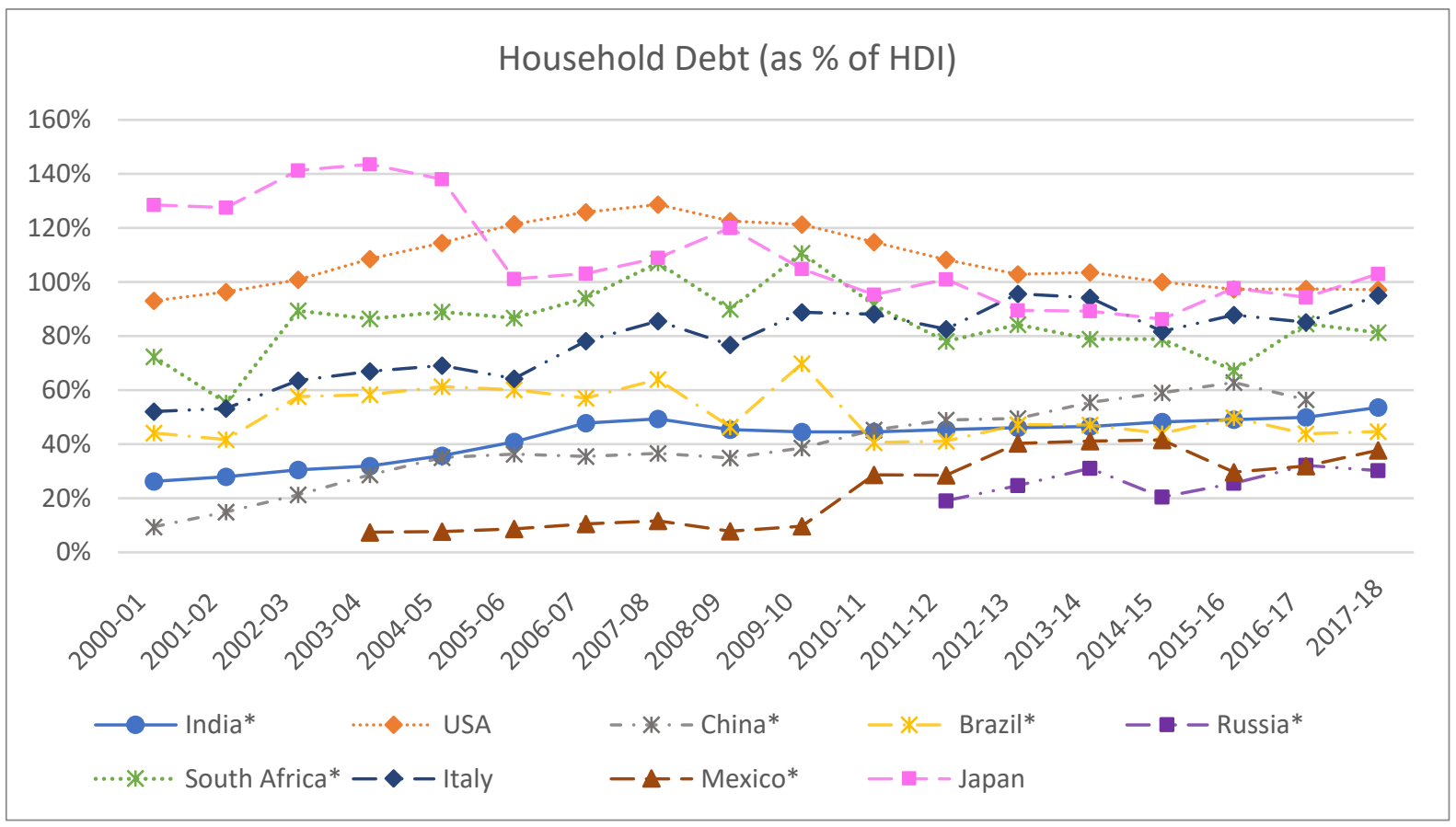

Figure 19. Evolution of household debt as proportion of household disposable income (* implies emerging economy). Source: Author calculations, OECD.Stat, and Shorrocks et al. (2019). 


\section{Concluding Remarks}

In this paper, we compile India's household balance sheet starting from 1970-71 to 2017-18 and use the compiled HBS to study the accumulation of financial wealth by the Indian household sector. Specifically, we begin by addressing some technical issues faced while compilation, including the definition of the "household" sector and assumption regarding the initial value of stock. Next, we cumulate the FoF data to arrive at the final Household balance Sheet presented in this paper. We study the evolution of the structure of Indian household finance over time and the constitution of asset classes making up the asset as well as the liability side of the balance sheet. Contrary to the everyday reporting by the financial press and also to the claim made by $\mathrm{RBI}$ (2019), we find that there has been neither a systematic decline in the share of Currency and Deposits combined in Indian households' portfolio nor a shift towards equities and debt securities over time. Interestingly, we found that the share lost by the asset class 'Shares and Debentures' between FY91 - FY18 was commensurate with the share gained by Life Insurance funds over the same period. This certainly makes the calculation of total exposure of the household sector to market risk difficult, as the reserves of life insurance funds comprise equities, bonds and other financial instruments that are in effect being held on behalf of the household sector, but at the same time households also enjoy explicit sovereign guarantee on their rights to many insurance benefits. More specifically, we find that in comparison to other parts of the world, households in India own a very small share of their financial wealth in the form of directly-held equities and debt securities. We observe that this is mainly due to the general preference of Indian households for liquid assets (currency and deposits) and the unique benefits like implicit or explicit sovereign guarantees, tax exemptions and fixed rates of return that come with investments in Provident and Pension Funds, Life Insurance Funds and Small Savings Schemes. 
We also compare our estimates of HBS with other estimates for India existing in the literature. Concurring with many other studies on Indian household finance, we too find that AIDIS grossly underestimates the level of indebtedness in the household sector. Moreover, the recently released HBS estimate (FY12 - FY18) along with RBI (2019) seems to have been compiled from FoF data that does not include OCVAs and hence overestimates both the stock of financial assets owned by the Indian households and the institutional household debt.

We observe that the Indian household sector, after witnessing a decade of balance sheet consolidation in the 1990s, has been in an upward leveraging cycle beginning from the period building up to the global financial crisis and the critical leverage ratios have remained at higher levels since then. Strikingly, this is not a global phenomenon; household sector in many major economies of the world repaired their balance sheets post-GFC and ended up with either lower or similar levels of leverage ratios (debt-to-liquid assets or debt-to-income ratio) in 2017-18 as compared to the numbers they had at the beginning of this millennium, whereas, indebtedness in Indian household sector has continued to climb up even during the global economic recovery period post-2010. If we just look at the household debt-to-wealth ratio, India appears to be among the least leveraged in the world. However, the picture becomes clearer when we look at the household debt-to-disposable income ratio-a critical measure of household debt-servicing capacity-which has more than doubled between FY01 - FY18. Alarmingly, this steady increase in debt-to-income ratio might be related to the phenomenon of households accumulating debt for supporting consumption - which has grown at a faster pace than disposable income every year since FY 2010-11. Subramanian \& Felman (2019) highlights the "Four balance sheet" challenge being faced by the Indian economy in recent years - the stress in infrastructure companies \& real estate sector on the corporate side, and banks \& NBFCs on the financial side. However, our findings reveal that there is a neglected, but equally important, fifth dimension to the country's deteriorating balance sheet-the Household 
Balance Sheet-which is the backbone of the domestic consumption. More precisely, a "Five balance sheet" challenge lies before India's growth juggernaut.

On the policy front, the increasing indebtedness of Indian households requires the utmost attention. If not done, it could catch the central bank by surprise since the data on total household debt is currently disseminated with a less-than-desirable frequency and is not monitored adequately. This holds serious implications for the formulation and efficacy of monetary policy. In view of that, synchronized efforts of Central Statistics Office (CSO), Reserve Bank of India (RBI) and academia are urgently needed to collect more and better data for compiling household balance sheets, both at the national and state levels and implement other recommendations of NSC (2018). As a first step, HBS should be regularly and timely published with the yearly statement of National Account Statistics. Data on household accounts is critical in identifying and understanding the sectoral linkages and spillover mechanisms, and in mapping the transmission of potential shocks across sectors, and therefore, higher frequency information on household finance becomes crucial for a closer macroeconomic assessment. Subsequently, the release of data on household finance should be made a quarterly exercise, at least at the national level. In this regard, it is important for the reader to know that the Reserve Bank of India published quarterly data on changes in household financial assets and liabilities for the first time in RBI (2018) for the period Q1:2015-16 to Q2:2017-18, but didn't continue the practice thereafter (as observed at the time of writing).

Finally, I would like to offer some caveats and suggestions which have direct implications for future avenues of research. Due to paucity of information, NPISHs such as political parties, religious societies, trade unions, social, cultural and recreational sports clubs, etc. are clubbed with the household sector in the National Accounts of India. Consequently, the estimates of HBS presented in this paper does not correct for the "true" size of the household sector. Also due to data constraints, 
we had made a zero-value assumption for the initial value of the stock while cumulating the FoF data for some items in the balance sheet. Moreover, in Section 4 where we compared the financial position of Indian households with those in other countries, we had used 2019 edition of Credit Suisse Global Wealth Databook (Shorrocks et al., 2019) as the source of data on household accounts for other countries. There do, however, exist other accounts of household wealth, especially for countries with questionable national accounting practices like China or Russia, which might differ from the estimates presented in GWD 2019; for example, the reader may notice that the estimates of household wealth for China presented in GWD 2019 are significantly different from those presented in Li (2018). In light of the above assumptions, the reader should focus more on the trends in the levels than the value of the level itself, especially while interpreting the findings from international comparative analysis. The Indian household balance sheets compiled in this article should be considered as an indicator of order of magnitude of financial wealth allocated across different instruments and certainly not as a substitute to official balance sheet estimates ${ }^{34}$, which, unfortunately, remain unavailable (or unreliable) at the time of writing.

The HBS compiled here could be further extended to include non-financial assets, viz. real estate, precious metals and household durables. At the moment, the only primary source of data for nonfinancial wealth owned by Indian households is the AIDIS and the subsequent estimates derived from various rounds of it, such as Shorrocks et al. (2019). These estimates are not entirely perfect and could be further improved. The biggest hurdle in this exercise is going to be lack of land records $\mathrm{s}^{35}$ and

\footnotetext{
34 The estimates of household financial wealth and institutional debt presented in this paper are certainly superior to survey estimates provided by last four rounds of AIDIS.

${ }^{35}$ The reader may note that Land administration and record-keeping is a State Subject in India as per the Seventh Schedule to the Constitution of India. It is a well-known fact that the land records in India are unclear (especially the cadastral maps) and do not guarantee ownership. In India, we have a system of registered sale deeds and not land titles. Consequently, property and land ownership is established through multiple documents maintained by different departments of State government (which usually work in silos), making it cumbersome to collate and access them. For the aforementioned reasons, Central government agencies like CSO depend on household surveys, such as AIDIS, for estimating the contribution of land and dwellings to household wealth.
} 
the rampant usage of 'black money' in the real estate and gold market. It is important to note that any exclusion of non-financial assets from HBS is a serious limitation as the Indian household sector holds at least $80 \%$ of its wealth in non-financial assets. On the liabilities side, it is important to realize that the share of non-institutional credit is very much significant in Indian household debt as uninsured households borrow frequently from non-institutional sources (RBI, 2017b). I have tried to incorporate the non-institutional debt in the HBS estimates presented in this paper by making some simplifying assumptions.

Although, we observed a steady rise in household debt-to-income ratio in India, the Indian household sector, as a whole, emerges financially sound from the perspective of debt-to-wealth ratio (an important measure of solvency risk), and the possibility of widespread household defaults does not seem imminent or likely. However, distributive aspects of household wealth and debt (and the associated risks) across regions and income cohorts are required to get a clearer picture of the extent of debt distress in the sector. The aggregated data, as provided by HBS, could aid in the investigation of such distributive aspects. Currently, AIDIS data is the only official source for measuring wealth distribution/inequality in India. However, there has been some debate over the reliability of wealth inequality estimates derived from AIDIS (Himanshu, 2019). Wealth surveys are generally subject to misreporting (generally under-reporting) of assets and debts by respondents, and differential response according to income or wealth level. To this end, HBS data could be used to adjust and improve AIDIS data and correct for non-sampling errors. There are different approaches to this: one, which has been applied by Wolff (2017) on US data, is to "align" the survey data with the HBS data, which means adjusting all holdings of a particular kind of asset or debt in the survey data in order to make its aggregate the same as is observed in the HBS data. Notice that this approach essentially ignores the differential response problem and maintains the hypothesis that all respondents misreport by the same percentage irrespective of their wealth level. The second approach relies on 
the assumption that irrespective of the source of the shortfall (of survey aggregates below HBS totals), the error due to under-reporting mainly affects mean wealth in the top X\% of the distribution; followed by fitting a Pareto distribution ${ }^{36}$ to the upper tail that is consistent with the adjusted survey estimate of the mean wealth of the top X\% households (refer Blanchet et al., 2017). It is hoped that my preliminary work would pave the way for further refinements aimed at improving the reliability of the relevant data, concepts, and estimation methods.

\section{Data and Statistical Appendix}

The Household Balance Sheet for India covering the period from FY 1970-71 to FY 2017-18 could be accessed at the following data repository: https://doi.org/10.7910/DVN/DPQPJY

\section{References}

1. Bell, C. (1990). Interactions between institutional and informal credit agencies in rural India. The world bank economic review, 4(3), 297-327.

2. Blanchet, T., Fournier, J., \& Piketty, T. (2017). Generalized Pareto curves: Theory and Applications. WID.world Working Paper 2017/3. World Inequality Database.

3. Chavan, P. (2012). Debt of Rural Households in India: A Note on the All-India Debt and Investment Survey. Review of Agrarian Studies, 2(1), 151-161.

4. CSO (2012). National Accounts Statistics: Sources and Methods. Central Statistics Office, Ministry of Statistics and Programme Implementation, Government of India. New Delhi.

5. Daniele, F. (Ed.). (2017). Understanding Financial Accounts. OECD Publishing. Paris.

6. Davies, J. B. (Ed.). (2008). Personal wealth from a global perspective. Oxford University Press.

7. Davies, J. B., \& Shorrocks, A. F. (2000). The distribution of wealth. Handbook of income distribution, 1, 605-675.

8. Davies, J. B., Lluberas, R., \& Shorrocks, A. F. (2017). Estimating the level and distribution of global wealth, 2000-2014. Review of Income and Wealth, 63(4), 731-759.

9. European Commission, International Monetary Fund, Organisation for Economic Co-operation and Development, United Nations, and World Bank. (2009). System of national accounts 2008.

10. Gothoskar, S. P. (1988). On some estimates of rural indebtedness. Reserve Bank of India Occasional Papers, 9(4), 299325.

11. Himanshu (2019). Inequality in India: A review of levels and trends. WIDER Working Paper 2019/42. Helsinki: UNUWIDER.

12. IMF (2011). Public Sector Debt Statistics: Guide for Compilers and Users. International Monetary Fund. Washington D.C.

13. IMF (2014). Government Finance Statistics Manual 2014. International Monetary Fund. Washington D.C.

14. Li, C. (2018). China's household balance sheet: Accounting issues, wealth accumulation, and risk diagnosis. China Economic Review, 51, 97-112.

15. Moore, T. (2007). India's emerging financial market: A Flow-of-Funds model. Routledge.

16. NSC (2018). Report of the Committee on Financial Sector Statistics. National Statistical Commission. Government of India. New Delhi.

${ }^{36}$ Pareto distribution often approximates the top tail of wealth distribution quite well (Davies, 2008 p. 412). 
17. NSSO (2013). Household Indebtedness in India, NSS 70th Round (January - December 2013). National Sample Survey Office, Ministry of Statistics and Programme Implementation, Government of India. New Delhi.

18. Piketty, T., Yang, L., \& Zucman, G. (2019). Capital accumulation, private property, and rising inequality in China, 19782015. American Economic Review, 109(7), 2469-96.

19. Prabhu, K. S., Nadkarni, A., \& Achuthan, C. V. (1988). Rural credit: mystery of the missing households. Economic and Political Weekly, 2642-2646.

20. Rajakumar, J. D., Mani, G., Shetty, S. L., \& Karmarkar, V. M. (2019). Trends and Patterns of Household Indebtedness. Economic \& Political Weekly, 54(9), 41.

21. Rao, K. R., \& Tripathi, A. K. (2001). Indebtedness of households: Changing characteristics. Economic and Political Weekly, 1617-1626.

22. RBI (2015). Manual on the Compilation of Flow-of-Funds Accounts of the Indian Economy. Reserve Bank of India. Mumbai. Retrieved on 20 Apr 2020 from: https://www.rbi.org.in/scripts/PublicationReportDetails.aspx?ID=824

23. RBI (2017a). Flows of Funds Accounts of the Indian Economy: 2015-16. Reserve Bank of India. Mumbai. Retrieved on 20 Apr 2020 from: https://www.rbi.org.in/Scripts/BS ViewBulletin.aspx?ld=17042

24. RBI (2017b). Indian Household Finance: Report of the Household Finance Committee. Reserve Bank of India. Mumbai. Retrieved on 20 Apr 2020 from: https://www.rbi.org.in/Scripts/PublicationReportDetails.aspx?UrlPage=\&ID=877

25. RBI (2018). Quarterly Estimates of Households' Financial Assets and Liabilities. Reserve Bank of India. Mumbai. Retrieved on 03 May 2020 from: https://www.rbi.org.in/Scripts/BS ViewBulletin.aspx?ld=17426

26. RBI (2019). Financial Stocks and Flows of the Indian Economy 2011-12 to 2017-18. Reserve Bank of India. Mumbai. Retrieved on 20 Apr 2020 from: https://www.rbi.org.in/Scripts/BS ViewBulletin.aspx?ld=18349

27. Shorrocks, A.F., Davies, J.B. \& Lluberas, R. (2018). Global Wealth Databook 2018, Credit Suisse Research Institute. Zurich.

28. Shorrocks, A.F., Davies, J.B. \& Lluberas, R. (2019). Global Wealth Databook 2019, Credit Suisse Research Institute. Zurich.

29. Subramanian, A., \& Felman, J. (2019). India's Great Slowdown: What Happened? What's the Way Out? CID Faculty Working Paper No. 370. Center for International Development, Harvard University.

30. Wolff, Edward N. (2017). A Century of Wealth in America. The Belknap Press of Harvard University Press. 